Document downloaded from:

http://hdl.handle.net/10251/120138

This paper must be cited as:

Rogríguez, O.; Eim, VS.; Roselló Matas, C.; Femenía, A.; Carcel Carrión, JA.; Simal, S. (2018). Application of power ultrasound on the convective drying of fruits and vegetables: effects on quality. Journal of the Science of Food and Agriculture. 98(5):1660-1673. https://doi.org/10.1002/jsfa.8673

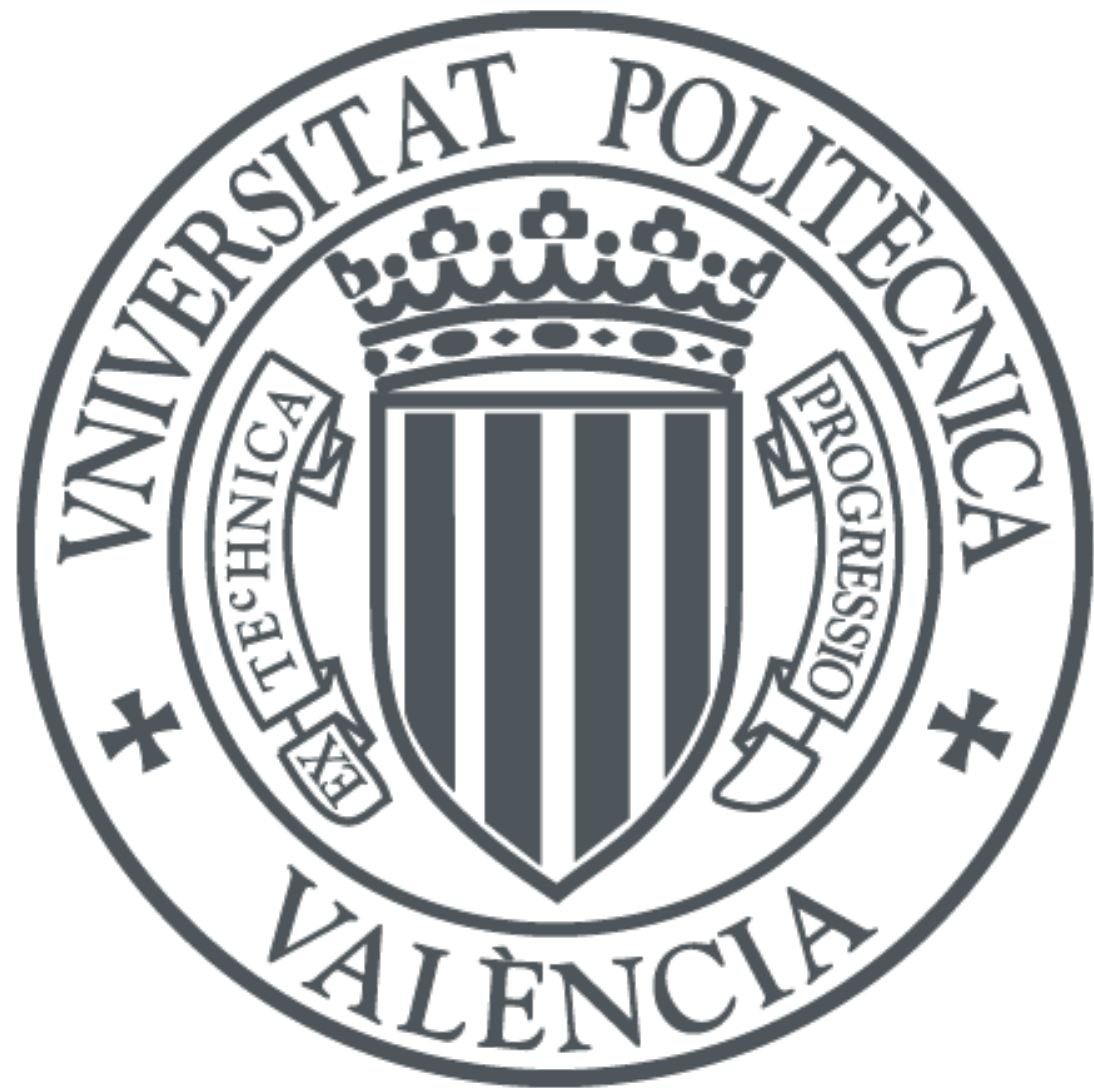

The final publication is available at

http://doi.org/10.1002/jsfa.8673

Copyright John Wiley \& Sons

Additional Information

This is the peer reviewed version of the following article:Rogríguez, Oscar, Eim, Valeria S., Roselló Matas, Carmen, Femenía, Antonio, Carcel Carrión, Juan Andrés, Simal, Susana. (2018). Application of power ultrasound on the convective drying of fruits and vegetables: effects on quality.Journal of the Science of Food and Agriculture, 98, 5, 1660-1673. DOI: 10.1002/jsfa.8673, which has been published in final form at http://doi.org/10.1002/jsfa.8673. This article may be used for non-commercial purposes in accordance with Wiley Terms and Conditions for Self-Archiving. 


\title{
Application of Power Ultrasound on the Convective Drying of Fruits and Vegetables: Effects on quality
}

\author{
Óscar Rodríguez ${ }^{1}$, Valeria Eim ${ }^{1}$, Carmen Rosselló ${ }^{1}$, Antoni Femenia ${ }^{1}$, \\ Juan A. Cárcel ${ }^{2}$, Susana Simal ${ }^{1}$ \\ ${ }^{1}$ Department of Chemistry, University of the Balearic Islands. Ctra Valldemossa km \\ 7.5, \\ 07122. Palma de Mallorca, Spain \\ ${ }^{2}$ ASPA Group, Food Technology Department, Universitat Politècnica de Valencia, Cno \\ Vera s/n, 46021 Valencia, Spain.
}

\begin{abstract}
Drying allows the obtaining of products with a long shelf life by reducing the water activity to a level low enough for the growth of microorganisms, enzymatic reactions, and other deteriorative reactions to be inhibited. Despite the benefits of this operation, the quality of heat sensitive products is diminished when high temperatures are used. The use of low drying temperatures reduces the heat damage but being the drying time longer, oxidation reactions occur and a reduction of the quality is also observed. Thus, drying is a method that lends itself to being intensified. For this reason, alternative techniques are being studied. Power ultrasound is considered an emerging and promising technology in the food industry. The potential of this technology relies on its ability to accelerate the mass transfer processes in solid-liquid and solid-gas systems. The intensification of the drying process by means of power ultrasound can be performed by modifying the product behavior during drying, using pre-treatments like soaking in liquid medium assisted acoustically or during the drying process itself applying power ultrasound in the gaseous medium. The purpose of this review is to provide a summary of the effects caused by the power ultrasound application on the quality of different dried products, such as fruits and vegetables when the acoustic energy is intended to intensify the drying process, either if the application is performed before as pretreatment or during the drying process.
\end{abstract}

\section{INTRODUCTION}

Drying is a mass and heat transfer operation widely used to reduce the water activity of the material. Convective drying is a high demanding energy operation that usually uses hot air to increase the food temperature and evaporate the water from the product.

This article has been accepted for publication and undergone full peer review but has not been through the copyediting, typesetting, pagination and proofreading process, which may lead to differences between this version and the Version of Record. Please cite this article as doi: 10.1002/jsfa.8673

This article is protected by copyright. All rights reserved. 
Nevertheless, a high increment of the temperature promotes organoleptic and nutritional changes in food products that may cause quality degradation. ${ }^{1}$ Therefore, low temperature drying has become an alternative to preserve the quality attributes. Moisture reduction can be achieved by evaporation if the drying temperature is above freezing point, or by sublimation if the temperature used is below freezing point. However, one of the main disadvantages in both cases is the low mass transfer rate of the process. ${ }^{2}$

During drying, water is transferred from inside the solid phase to the surface and then from the surface to the fluid phase. Considering negligible the resistance of the interphase, the global mass transfer can be considered as the result of two resistances: ${ }^{3}$

- Internal resistance: given by the characteristics of the material and the temperature.

- External resistance: because of the interaction between the surface of the solid and the fluid phase.

So, convective drying is prone to be intensified in terms of kinetics, however, the quality of the final food product should be considered. ${ }^{4}$ In order to achieve an intensification of the drying process, several technologies have been tested such as microwave heating, ${ }^{5,6}$ high pressure, ${ }^{7-9}$ electric pulses ${ }^{10}$ and power ultrasound. ${ }^{11-13}$

Nowadays, power ultrasound (PU) is considered a promising and emerging technology in the food industry. The interest on this technique relies on its capacity to accelerate the mass transfer process due to its effect on both; the internal and the external resistances to mass transfer, and also on its versatility for being applied either on solid-liquid systems (as pre-treatment before drying) and on solid-gas systems (during drying). ${ }^{14,15}$ The effects of PU application on the quality of the food product vary according the structure and nature of the food product, the propagation medium (gas, liquid, solid), and the properties of the acoustic wave (frequency, power, attenuation, impedance). ${ }^{16}$

The aim of this paper is providing a critical review of the effects of the PU application on the quality of dried food products, either when it is applied before the drying process as pretreatment or during the drying process as a complementary technology. A summary of the research papers referred in this review is presented in Table 1 for those considering

This article is protected by copyright. All rights reserved. 
the PU application as pre-treatment and in Table 2 for those considering the use of PU during the convective drying. In both tables, it has been collected the most relevant aspects about product, conditions of the PU application and drying parameters, together with the quality attributes studied.

\section{BASIC PRINCIPLES OF POWER ULTRASOUND}

Acoustic waves are mechanical waves travelling through a conductive elastic medium producing mechanical oscillations. When the frequency of the acoustic waves is higher than the upper audible human limit $(20 \mathrm{kHz})$ they are considered ultrasound. ${ }^{17}$ In general terms, the generation system of ultrasonic waves is constituted by three main elements: a generator, a transducer and an emitter. The generator transforms the electrical signal into the selected frequency; the transducer, which is a vibrating body, converts the high frequency electrical signal into mechanical vibrations, and the emitter radiates the mechanical vibrations to the medium. ${ }^{13}$

Ultrasonic waves are characterized by different parameters, and their effects rely on the suitable selection and control of those parameters. The applied ultrasonic power (W) determines the effect of the acoustic energy on the material (food product). Thus, in diagnosis or monitoring applications, when the purpose is mainly the characterization of the food, high frequencies are considered $(0.5-10 \mathrm{MHz})$, to increase the sensitive of the procedure, and low acoustic power is applied (less than $10 \mathrm{~kW} \mathrm{~m}^{-2}$ ) to avoid some influence on the inspected product. On the contrary, when the purpose is to produce permanent changes in the propagation medium provoking disruptions or inducing physical, mechanical or chemical/biochemical changes, the power used is higher and constitute the area of high-intensity ultrasound or power ultrasound. Depending on the properties of the material, alterations are directly proportional to the ultrasonic power. ${ }^{18}$ Moreover, because the losses of acoustic energy increase with the frequency, frequencies greater than $20-50 \mathrm{kHz}$ are not usually used in these last applications.

Regarding the acoustic energy transferred by the system to the material, an important issue must be raised concerning to the units used for its expression. Different units have been used in literature and they include traditional power units (W), ${ }^{19-21}$ acoustic density units referring to the volume $\left(\mathrm{W} \mathrm{m}^{-3}\right),{ }^{4,22,23}$ where the acoustic energy is applied, or considering the irradiation area $\left(\mathrm{W} \mathrm{m}^{-2}\right) \cdot{ }^{24-26}$ Authors of this review ponder thoroughly

This article is protected by copyright. All rights reserved. 
the necessity of making the expression of the real (not nominal) applied acoustic energy more homogeneous in order to facilitate on one hand, the replication of the study conditions, and on the other hand the comparison of the attained results.

The effects of ultrasound are highly dependent of two main parameters related with ultrasonic transmission, the attenuation coefficient and the acoustic impedance. They correlate with some physicochemical properties of the material where the acoustic energy is applied. Attenuation is the intensity loss of the wave when it travels through the medium due to the friction of molecules provoked by the compression and dilatation stress. The attenuation capacity is a characteristic of each material and can influence on the effectiveness of ultrasound application. Thus, in solid-liquid applications, the highly attenuant liquids can prevent that acoustic waves arrive to the solids with enough energy to produce significant effects. The acoustic impedance is related with the resistance of the medium to the propagation of the acoustic wave. At interfaces, the difference of impedance between media define the amount of acoustic energy is transferred or reflected. Thus, the great difference of impedance between solid or liquid and gas media ${ }^{27}$ makes very difficult the transmission of acoustic waves and then, the effects produced by ultrasound.

\section{ULTRASONIC PRETREATMENTS IN FOOD PRODUCTS}

When applied in a liquid medium, the acoustic waves produce cavitation. Bubbles or voids are formed, grown and collapsed due to the pressure fluctuation provoking sudden and localized increments in both temperature and pressure. ${ }^{19,27}$ The magnitude of the cavitation depends on the parameters of the acoustic wave (frequency, intensity) and the properties of the medium (viscosity, surface tension, vapor pressure, temperature, presence of dissolved gases). The implosion of cavitation bubbles close to the solid-liquid interface may cause the generation of a microjet into the bubble, which moves through and leave it striking the solid surface. This microjet raises the mass and heat transfers between the liquid and the solid by breaking the respective diffusion boundary layers. ${ }^{12}$, 21

Acoustic energy during the interaction with the medium is converted into thermal energy, therefore heating is observed during the PU application. ${ }^{24,28}$ When the acoustic wave interacts with the solid causes turbulences in the solid-liquid interphase affecting mainly

This article is protected by copyright. All rights reserved. 
the diffusion boundary layer and modifying the structure of the solid. ${ }^{29}$ Once the wave reaches the solid, alternative compressions and expansions are produced resulting in a sponge effect in the solid, which helps the liquid to flow out of the solid in an interchange with the entry of fluid from outside. This mechanical stress also can create microscopic channels that may ease the mas transport. ${ }^{12,19,25}$

\section{DEVICES}

Mostly two types of devices are used in the PU application in liquid medium: ultrasonic baths and ultrasonic probes and they differed in its effectiveness, efficiency and capability.

Commercial ultrasonic baths are available in different tank capacities, ultrasonic powers or frequencies. Adjustable wave amplitude and the control of temperature made them suitable for laboratory or industrial applications. The acoustic field produced by ultrasonic baths is very irregular due to the reflections of acoustic waves with bath walls and liquid-gas interface. Moreover, cavitation occurs heterogeneously through the tank and induces wave reflections, so the sonication effect it is unequally distributed. One of the main drawback of using ultrasonic baths is the low ultrasonic intensity capacity. The indirect application makes the wave not only has to travel through the liquid in the tank but also must cross the sample container, therefore the acoustic intensity that arrives to the sample is lower than expected; besides, the reflection of the acoustic waves in the ultrasonic bath makes the repeatability and scalability of the process very difficult. ${ }^{30,31}$ Ultrasonic baths have been used in the pretreatment of banana, ${ }^{12,}{ }^{32}$ pineapple, ${ }^{33}$ guava, ${ }^{19}$ carrot,${ }^{20,21}$ apple, ${ }^{34,} 35$ blueberry, ${ }^{36}$ cherry, ${ }^{37}$ malay apple, ${ }^{38}$ melon, ${ }^{26}$ mushrooms, ${ }^{39}$ papaya, ${ }^{40}$ and strawberry ${ }^{38}$. A direct application of PU on liquid media can be achieved by using ultrasonic probes. The different geometries of probes can permit to transmit (cylindrical) or concentrate (conical, stepped) the ultrasonic energy. ${ }^{2}$ The sonication time depends on the specific treatment but usually ranges between 0.5 and $5 \mathrm{~min}$. During the performance, the probe is immersed in the liquid medium and acoustic energy is directly given. An intense sonication zone (ca. 100 times higher than the average ultrasonic bath) can be identified directly beneath the probe and the ultrasonic irradiation distance is limited to a certain area of the probe's tip, therefore small volumes are recommended to keep dead zones to minimum. ${ }^{16}$. Ultrasonic probes have been used in the pretreatment of apple, ${ }^{24,}{ }^{41}$ guava, ${ }^{19}$ mushrooms, brussels and cauliflower, ${ }^{25}$ carrot, ${ }^{42}$ blackberry, ${ }^{22}$

This article is protected by copyright. All rights reserved. 
mulberry ${ }^{43}$ and parsley leaves. ${ }^{44}$ Table 1 collects the description of the pretreatment conditions, drying conditions and quality parameters considered when PU was applied as pretreatment by using ultrasonic bath or probe.

\section{PROPAGATION MEDIUM}

The selection of the liquid medium used in the ultrasonically assisted pretreatment depends on of the desired outcome. Thus, the $\mathrm{pH}$ or solute concentration can induce a great influence in the effect of the acoustic energy on the food product and the interaction between the solid and the surrounding medium. One of the most common solution for osmotic pretreatments of fruits is sucrose dissolved in distilled water. ${ }^{26,32}$ Thus, the osmotic dehydration of banana, ${ }^{12}$ pineapple, ${ }^{14}$ guava, ${ }^{19}$ blueberry, ${ }^{36}$ cherry, ${ }^{37}$ melon, ${ }^{26,} 45$ papaya,${ }^{40}$ malay apple,${ }^{38}$ apple, ${ }^{46}$ strawberry, ${ }^{47}$ carrot,${ }^{48}$ have been carried out using sugar solutions ranging from 30 to $70{ }^{\circ} \mathrm{Brix}$. In these studies, the acoustic assistance was done mainly by using ultrasonic baths and the applied ultrasonic power varied from 60 to 2500 $\mathrm{W}$ operated at 25 or $40 \mathrm{kHz}$. Garcia-Noguera et al. ${ }^{47}$ reported that PU application using an ultrasonic bath $(25-40 \mathrm{kHz})$ on strawberry halves immersed in 25 and $50{ }^{\circ}$ Brix solutions promoted a steep increase in water loss, which may be related to the formation of microscopic channels and breakdown of tissue cells. Kek et al. ${ }^{19}$ observed that increasing osmotic solution concentration from 35 to $70{ }^{\circ}$ Brix resulted in a significant increase in water loss of guavas due to the increase in the concentration gradient between the soluble solids in the fruit and in the osmotic solution. According to these authors, the PU application $\left(1.0-2.5 \mathrm{~kW}\right.$ ) promoted a gain of solid content (sugar) of $0.05 \mathrm{~g} \mathrm{~d}^{\mathrm{m} \mathrm{g}} \mathrm{g}^{-1}$

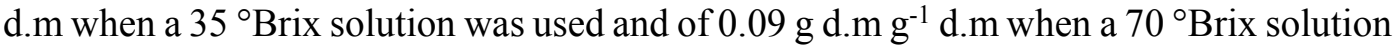
was used. Regarding the water loss, both the use of ultrasonic bath or probe promoted a similar trend where water loss increased slightly when ultrasound input was increased. When ultrasonic bath was used, the water loss ranged from 0.11 to $0.11 \mathrm{~g}$ water $\mathrm{g}^{-1} \mathrm{~d} . \mathrm{m}$ while when ultrasonic probe was used it ranged from 0.07 to $0.11 \mathrm{~g}$ water $\mathrm{g}^{-1} \mathrm{~d} . \mathrm{m}$. In all cases, the ultrasonic assistance increased the efficiency of the total osmotic dehydration process. Carcel et al. ${ }^{46}$ reported that the higher the ultrasonic power applied the higher the solid gain and the water loss. Thus, working with apple slices during $45 \mathrm{~min}$ of treatment in a $30{ }^{\circ}$ Brix sucrose solution at $30{ }^{\circ} \mathrm{C}$, these authors found a solid gain and water loss of $0.4 \mathrm{~g}$ water $\mathrm{g}^{-1} \mathrm{~d} . \mathrm{m}$ and $0.9 \mathrm{~g} \mathrm{~d} . \mathrm{m} \mathrm{g}^{-1} \mathrm{~d} . \mathrm{m}$ respectively at $3.6 \mathrm{~W} \mathrm{~cm}^{-2}$, and 0.6 g water $\mathrm{g}^{-1} \mathrm{~d} . \mathrm{m}$ and $1.4 \mathrm{~g} \mathrm{~d} . \mathrm{m} \mathrm{g}^{-1} \mathrm{~d} . \mathrm{m}$, respectively at $11.5 \mathrm{~W} \mathrm{~cm}^{-2}$. A different result was observed by Siucinska et al. ${ }^{37}$ in the acoustically assisted $\left(0.4 \mathrm{~W} \mathrm{~cm}^{-2}\right)$ osmotic

This article is protected by copyright. All rights reserved. 
dehydration of cherry using a $60{ }^{\circ}$ Brix solution at $40{ }^{\circ} \mathrm{C}$ during 30 to $120 \mathrm{~min}$. These authors did not observe significant differences among samples treated under different condition, however, the average solid gain and water loss were of $0.3 \mathrm{~g} \mathrm{~d} . \mathrm{m} \mathrm{g}^{-1} \mathrm{~d} . \mathrm{m}$ and $3.0 \mathrm{~g}$ water $\mathrm{g}^{-1} \mathrm{~d} . \mathrm{m}$, respectively in treated cherries.

Generally, when distilled water is used, the food product exhibits a gain of water content and a reduction of solid matter due to the mass transfer exchange promoted by the solute gradient between the food product and the surrounding media. ${ }^{38,49}$ These mass transport is enhanced by the PU application. As an example, Fernandes et al. ${ }^{12,14,26}$ used distilled water (as control) in the study osmotic dehydration of banana, pineapple and melon, respectively. In all these cases, the PU application $\left(4780 \mathrm{~W} \mathrm{~m}^{2}\right)$ up to $30 \mathrm{~min}$ promoted

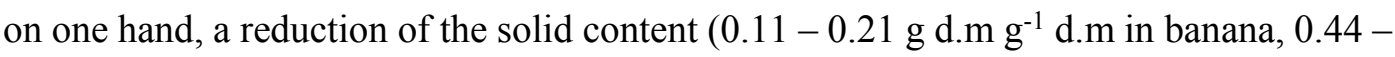

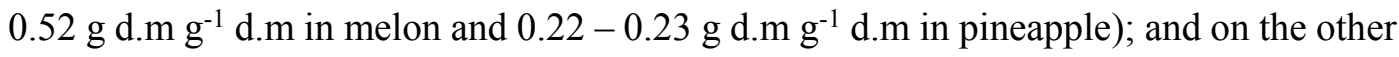
hand, a gain of moisture content $\left(0.04-0.11 \mathrm{~g}\right.$ water $\mathrm{g}^{-1} \mathrm{~d} . \mathrm{m}$ in banana, $0.08-0.09 \mathrm{~g}$ water $\mathrm{g}^{-1} \mathrm{~d} . \mathrm{m}$ in melon and $0.02-0.03 \mathrm{~g}$ water $\mathrm{g}^{-1} \mathrm{~d} . \mathrm{m}$ in pineapple).

The use of the self-juice of the fruit has been recently used in few researches with the purpose of evaluating the effect of the PU application when the liquid medium and the food product are of the same nature, consequently no water nor solid gradients were present in the system. Rodriguez et al. ${ }^{24}$ used apple juice $\left(\mathrm{pH}=3.3 ;{ }^{\circ} \mathrm{Brix}=11.6\right)$ in the pretreatment of apple parallelepipeds by using an ultrasonic probe $\left(2.1\right.$ and $12.9 \mathrm{~W} \mathrm{~cm}^{-}$ ${ }^{2}$ ). These authors did not observe any significant change in the moisture content of the samples after 5 min treatment. Besides, during drying $\left(50^{\circ} \mathrm{C}, 1 \mathrm{~m} \mathrm{~s}^{-1}\right)$ a similar kinetic was observed among samples immersed in juice being the average, however apples treated with juice and PU $\left(12.9 \mathrm{~W} \mathrm{~cm}^{-2}\right)$ exhibited a reduction of the drying time of $33.1 \%$ compared with the untreated sample. Pineapple juice $\left(\mathrm{pH}=3.4 ;{ }^{\circ}\right.$ Brix $\left.=12.2\right)$ was used by Rodriguez et al. ${ }^{33}$ as medium during the acoustic pretreatment $\left(5.1 \mathrm{~W} \mathrm{~L}^{-1}\right)$ of pineapple cubes. Compared to the untreated sample, after $30 \mathrm{~min}$ of treatment, the increment of the moisture content was of $6 \%$ and $10 \%$ in samples treated without and with acoustic assistance, respectively. Regarding the drying kinetics, compared to the untreated sample, samples immersed in pineapple juice and sonicated using an ultrasonic bath exhibited a drying time reduction $\left(50^{\circ} \mathrm{C}, 0.5 \mathrm{~m} \mathrm{~s}^{-1}\right)$ of 4.6 and $9.0 \%$ for 20 and 30 min of pretreatment. It is worth pointing out that the increase in the initial moisture content of treated samples is indicative of the water intake during the treatment, being higher due to the ultrasonic

This article is protected by copyright. All rights reserved. 
waves, but this water might have a free character inside the fruit tissue, leading to a weak interaction with the solutes in the sample and an easier removal during the convective drying process under these conditions.

\section{ULTRASONIC ASSISTED DRYING}

Power ultrasound can be also directly applied to intensify the convective drying. In this case the effects of ultrasound are mainly mechanical and no significant overheating of the material being dried take place. ${ }^{50}$ The acoustic vibration produced by ultrasound generates a successive compression and expansion of the material, leading to an stress of the structure ("'sponge effect') ). This mechanical force can create microscopic channels that allow an easier inner water movement. ${ }^{2,32,51}$ Moreover, PU application can produce cavitation which takes place in the liquid phase inside the moist solid. The asymmetric implosions of cavitation bubbles near to the solid surface, can lead to the partial release of some water bounded to the solid structure. All these mechanical effects results in a reduction of the internal resistance to mass transport. ${ }^{52}$ Regarding the external resistance, the acoustic waves reduce the boundary layer thickness due to different effects such as pressure variations, oscillating velocities and micro-stirring on the solid-gas interface. The reduction of the boundary layer allows an improvement of the vapor transfer rate from the solid surface to the drying air. ${ }^{28,53}$

Two main handicaps must be overcome to achieve an efficient application of PU on gas media. On the one hand, the mismatch between gases and solids or liquids due to the acoustic impedance differences makes the transfer of the acoustic energy generated into the air to the solid very difficult. On the other hand, gases media are very attenuating media that significantly reduces the acoustic energy applied to the materials being dried. ${ }^{20}$, ${ }^{54}$ Currently different systems have been developed to efficiently transmit the acoustic energy from the emitter to the solid during the convective drying in any of its most conventional procedures: hot-air drying and low temperature drying and two different configurations have been used: contact and contactless systems. ${ }^{16,53,55}$

A first attempts to apply power ultrasound in drying processes was carried out by direct contact between transducer and samples. Thus, ultrasonic vibrations are directly transmitted to the sample. Stepped plate transducers constitute a good option as a contact system due to their high radiating surface. Some average characteristics of these kind of

This article is protected by copyright. All rights reserved. 
transducers are a beam width (at $3 \mathrm{~dB}$ ) of 1.5 degrees, power capacities up to $2 \mathrm{~kW}$, and intensity levels reached in air as high as $175 \mathrm{~dB}$. Its efficiency ranges about $80 \% .^{53,55,56}$ The good acoustic impedance matching between the stepped plate transducer and the food material favors the deep penetration of acoustic energy. These systems showed a very intense effect which can be increased if low static pressure is applied on the sample. This system has been used in the drying of apple ${ }^{53}$ and carrot. ${ }^{57}$ Nevertheless, the scaling up of these option to an industrial level is quite difficult. ${ }^{13}$

Another ultrasonic system used consisted of a ring sonotrode driven by an ultrasound processor which works at a frequency of $24 \mathrm{kHz}$. Although the system was initially created for ultrasonic sieving, it was equipped with a laboratory drying screen where the sample could be placed and the acoustic energy transmitted. ${ }^{58}$ The whole system is placed inside the drying oven and the drying air passes perpendicularly to the sample. This system has been used in the drying of potato, ${ }^{59}$ apple ${ }^{60}$ and bell pepper. ${ }^{61}$ When drying at $70{ }^{\circ} \mathrm{C}$, compared to non-sonicated samples, the use of the ring sonotrode promoted savings in the drying time of 10,27 and $23 \%$ in potato, apple and red bell pepper, respectively.

The development of specific ultrasonic transducers with higher power capacities have partially solved the problems observed in the contact systems application. ${ }^{62}$ One of the most popular contactless system is the aluminum vibrating cylinder (AVC) driven by a piezoelectric composite transducer $(21.8 \mathrm{kHz})$ capable of converting the electric energy in vibration movement generating a high-intensity ultrasonic field inside the cylinder (75 $\mathrm{W}, 154.3 \mathrm{~dB}$ ) with a relative low energy consumption. ${ }^{63-66}$ Thus, cylinder is used as a vibrating drying chamber. This system has been used in the drying of several fruits and vegetables like apple, ${ }^{1,23,64,65}$ cassava $^{4}$, tomato, ${ }^{67}$ strawberry, ${ }^{51}$ orange peel, ${ }^{68}$ potato, ${ }^{66}$ carrot ${ }^{69}$ eggplant, ${ }^{70}$ grape skin, ${ }^{71}$ passion fruit peel. ${ }^{72}$ Different process conditions like air temperature and velocity, mass load, and applied ultrasonic power have been tested using this system.

Other kind of transducers for air borne ultrasonic application are the plate (stepped or not) transducers. With one of this, a laboratory hybrid chamber dryer equipped with an ultrasonic airborne system $(26 \mathrm{kHz}, 200 \mathrm{~W})$ and microwave generator (100 W) was developed. $58,73,74$ Thus, the apparatus allows the drying process with the use of thermal 
(hot air), acoustic and microwave energy separately or simultaneously. Kowalski et al. ${ }^{52}$ used this set-up in the acoustically assisted drying $\left(100 \mathrm{~W}, 45^{\circ} \mathrm{C}\right)$ of apple slices and reported a reduction of $32 \%$ in the drying time when applying PU. The effect of the microwave energy $(100 \mathrm{~W})$ during the acoustic assisted drying $\left(100-200 \mathrm{~W}, 55^{\circ} \mathrm{C}\right)$ of raspberry, ${ }^{58}$ being the reduction in the drying time of $79 \%$ with the microwave assistance and $59 \%$ without it. The effect of the microwave energy used only in the first stage on the acoustically assisted drying process was studied by Szadzińska et al. in strawberry ${ }^{73}$ (first $30 \mathrm{~min}$ ) and green pepper ${ }^{74}$ (first $10 \mathrm{~min}$ ). These authors concluded that dosing the microwave radiation improved the drying kinetics without risking the quality of the dried product which can be affected by the vibration and heating effect. In both studies, the energy consumption was significantly reduced in 50 and $20 \%$, respectively.

Table 2 collects the description of the drying conditions and quality parameters considered when PU was applied to intensify the drying process.

\section{ON THE QUALITY OF THE DRIED PRODUCT}

During drying, food products undergo physical, structural, chemical, organoleptic and nutritional alterations that cause quality changes. The extent of the changes depends on the characteristics of the food matrix, and the process conditions. These process conditions includes the combination of pretreatment (if any) and drying and the assistance of power ultrasound on the pretreatment or during drying. Therefore, the process variables and the PU parameters should be selected properly to limit the irreversible changes in the food quality that risks its commercial acceptance in the market.

\section{STRUCTURE}

As it was mentioned before, ultrasonic waves induce structural changes that can make easy the mass transport. Those structural changes have been analyzed by means of techniques like scanning electron microscopy (SEM), ${ }^{37,64,72,75}$ cryo-SEM ${ }^{4,68,70}$ or light microscopy. ${ }^{26,38,41,47,49}$ The extent of these changes mainly depends on the ultrasonic intensity and the porosity $(\varepsilon)$ of the food product. Thus, the sponge effect is more important in high-porosity products (like eggplant or orange peel) due to the large intercellular spaces, therefore a lower ultrasonic intensity level is needed to promote the water removal. ${ }^{54}$

This article is protected by copyright. All rights reserved. 
In the pretreatment of melon $(\varepsilon=0.133)^{76}$ using osmotic solutions $\left(25-70{ }^{\circ} \mathrm{Brix}\right)$ without acoustic assistance, the cell wall weakened due to solubilizing of pectin together with the high osmotic pressure, therefore water transport became easier and effective water diffusivity increased. ${ }^{26}$ However, when PU was applied on a middle porosity product like strawberry $(\varepsilon=0.471)^{76}$ using an ultrasonic bath $\left(25,40 \mathrm{kHz}, 4870 \mathrm{~W} \mathrm{~m}^{-2}\right)$, smaller and needle shaped cells were observed proving the formation and appearance of microchannels formed by the elongation and flattening of cells in some regions of the sample. ${ }^{47}$ In apple $(\varepsilon=0.233)^{4,76}$, the PU application by means of an ultrasonic probe $(2.1$, $19.9 \mathrm{~W} \mathrm{~cm}^{-2}$ ) using distilled water as medium promoted a relative increase in cell separation and cellular collapse probably associated with extensive damage to the cell walls and membranes produced by the acoustic waves. This damage was more evident when low-pH media like apple juice or $1 \%$ citric acid solution were used. ${ }^{24}$

The effect of the PU application during the convective drying on the structure of the product has been also studied. As an example, when PU was applied during hot air convective drying of eggplant $(\varepsilon=0.423)^{77}$ at $40^{\circ} \mathrm{C}\left(1 \mathrm{~m} \mathrm{~s}^{-1}\right)$, the alternating expansions and contractions promoted the degradation of the endocarp cells, the effect was more intense at a lower acoustic power of $18.5 \mathrm{~W} \mathrm{~L}^{-1}(3.5 \mathrm{~h})$ than when the acoustic power was of $37.0 \mathrm{~W} \mathrm{~L}^{-1}(1.8 \mathrm{~h}) .{ }^{70}$ However, these authors observed that eggplant samples dried without ultrasonic assistance exhibited a more noticeable degradation of the endocarp cells, which was related to the longer extension of the drying process $(7 \mathrm{~h})$. In orange peel $(\varepsilon=0.330)^{4}$ drying $\left(40{ }^{\circ} \mathrm{C}, 1 \mathrm{~m} \mathrm{~s}^{-1}\right)$, the albedo was disrupted by the drying air and the cell tubular shape disappeared while the water is released. The PU application $(21.7 \mathrm{kHz} ; 45$, $90 \mathrm{~W}$ ) promoted a higher collapse of the cell structure due to a more intense disruption of the albedo cells. Also, the spread of waxy compounds (flavedo) in the coticule was more evident when PU was applied. ${ }^{68}$

When applying PU on low-porosity products like cassava ${ }^{4}$ or potato ${ }^{59}$ changes in the microstructure were observed but in a lower degree. Probably, the dense structure of these products makes difficult the transmission of ultrasonic energy at the interface with the drying air and this fact did not allow the creation of microchannels for the removal of moisture from the inner cell layers. Cassava $(\varepsilon=0.029)$, with a hard and compact structure 
composed by tightly-joined cells along the cell walls did not exhibited a severe structure change after the PU application $\left(6-31 \mathrm{~kW} \mathrm{~m}^{-3}\right)$ during drying at $40{ }^{\circ} \mathrm{C}$; however, compared with the not acoustically assisted sample, an increment in the $D_{e}$ figure from 7 to $56 \%$ was observed. ${ }^{4}$ Cell injury was measured in potato $(\varepsilon=0.060)$ cylinders during drying $\left(70{ }^{\circ} \mathrm{C}\right)$ assisted by PU application (42 W) using a ring sonotrode. ${ }^{59}$ It was observed that the extent of the cell injury was directly related to the acoustic energy applied instead of the water removal achieved, it was also observed that the injury was strongly reduced in the inner layers of the sample being more noticeable in the surface of the samples.

The combined effect of ultrasound application and drying temperature can significant influence the structure of the product. In this sense, ultrasonically assisted drying with acoustic densities of 18.5 and $30.8 \mathrm{~kW} \mathrm{~m}^{-3}$ at high temperature air drying of apple $(\varepsilon=0.233)^{4}$ showed that the disruption of the cell structure and enlargement of the porous, being more evident at $30{ }^{\circ} \mathrm{C}$ than at $50{ }^{\circ} \mathrm{C}$ (shorter drying time); however at $70{ }^{\circ} \mathrm{C}$, the tissue was clearly devastated, and cells collapse, holes and disruptions were observed. ${ }^{64}$ Wen drying took place at low temperature with an applied acoustic density was of 20.5 $\mathrm{kW} \mathrm{m}{ }^{-3}$, the structure of apple dried at $-10^{\circ} \mathrm{C}$ was more porous than the one dried at 10 ${ }^{\circ} \mathrm{C}$, probably as consequence of the growth of crystals during the sample's freezing. Nevertheless, the PU application induced a greater degradation of the sample structure at both temperatures which was reflected in the appearance of more pores with higher diameters. ${ }^{23}$

\section{REHYDRATION CAPACITY}

Rehydration takes place in three different stages: the imbibition of water into the dried material, the swelling, and the leaching of soluble solids, and its rate is linked to the cellular damage and the structural disruption suffered by the sample during the drying process. ${ }^{34,78}$ As a general rule, the application of PU before or during the drying process promoted an increment of rehydration capacity (RC) of dried samples compared to samples dried without PU application. Moreover, in some cases, the lower acoustic intensity applied, the higher RC observed. For instance, the RC of dried mushroom, Brussel sprout and cauliflower was studied at $80^{\circ} \mathrm{C}$ in samples acoustically treated before drying using either an ultrasonic bath $\left(0.5 \mathrm{~W} \mathrm{~cm}^{-2}\right)$ or an ultrasonic probe $\left(39-43 \mathrm{~W} \mathrm{~cm}^{-}\right.$

This article is protected by copyright. All rights reserved. 
$\left.{ }^{2}\right) .{ }^{25}$ In this study, the highest RC was achieved in samples pretreated at the lowest acoustic intensity (ultrasonic bath) during the shortest time under studied ( $3 \mathrm{~min}$ ), while the samples dried without pretreatment showed the lower RC. The application of a higher acoustic intensity during pretreatment provoked the loss of turgor and the deterioration of the cell wall, therefore the loss of the rehydration capacity of these dried vegetables.

Fijalkowska et al. ${ }^{34}$ acoustically pretreated $\left(3-4 \mathrm{~W} \mathrm{~cm}^{-2}\right)$ apple slices for $30 \mathrm{~min}$, and then dried them at $70{ }^{\circ} \mathrm{C}, 2 \mathrm{~m} \mathrm{~s}^{-1}$. These authors reported that after $3 \mathrm{~h}$ of rehydration at $20{ }^{\circ} \mathrm{C}$ no significant differences were observed among pretreated and untreated samples. However, Mothibe et al. ${ }^{41}$ observed that PU application by using an ultrasonic probe (25 $\mathrm{kHz}, 200 \mathrm{~W}$ ) during $5-15$ min of apple slices before drying at $70^{\circ} \mathrm{C}$ promoted an increase between 19.6 - $22.1 \%$ of the RC compared with the untreated sample when they were immersed in boiling water for $2 \mathrm{~min}$. The $\mathrm{RC}$ at $25^{\circ} \mathrm{C}$ of acoustically pretreated (41 W $\mathrm{L}^{-1}$ ) carrot slices dried at 40 and $60{ }^{\circ} \mathrm{C}$ was studied by Ricce et al. ${ }^{20} \mathrm{RC}$ of samples subjected to ultrasonic pretreatment at both 30 and 60 min was greater compared to untreated samples, which can be attributed to the higher porosity and micro-channels formation during the pretreatment. Gamboa-Santos et al. ${ }^{21}$ studied the effect of acoustic pretreatments $(20 \mathrm{kHz}, 400 \mathrm{~W})$ during $10 \mathrm{~min}, 60^{\circ} \mathrm{C}$ (minced carrot) and $15 \mathrm{~min}, 70^{\circ} \mathrm{C}$ (sliced carrot) before drying at $46{ }^{\circ} \mathrm{C}$ of temperature and $4.9 \mathrm{~m} \mathrm{~s}^{-1}$ of air velocity on the $\mathrm{RC}$. These authors found that the RC of acoustic pretreated samples was higher than the one of samples minced or sliced blanched with boiling water or steam at $98{ }^{\circ} \mathrm{C}$ for 1 or 2 min, respectively.

Santacatalina et al. ${ }^{79}$ studied the RC $\left(30^{\circ} \mathrm{C}\right)$ of eggplant dried at $-10{ }^{\circ} \mathrm{C}$ and $10{ }^{\circ} \mathrm{C}$ with the application of PU $(50 \mathrm{~W})$. Although PU application caused a faster water intake, it did not lead to greater final water absorption after rehydration at $30{ }^{\circ} \mathrm{C}$ compared with the sample dried without acoustic assitance. ${ }^{79}$ Similarly, the PU application $(76-110 \mathrm{~W})$ during freeze drying $\left(-30^{\circ} \mathrm{C}\right)$ of red bell pepper did not promote a significant change of the RC (using boiling water) compared with sample dried without acoustic assistance. ${ }^{61}$

\section{WATER MOBILITY}

The modification of the structure of the sample (cell walls deformation, lysis of membranes, tissue shrinkage) plays an important role in the mobility of water and solids during processing. ${ }^{24}$ Time domain nuclear magnetic resonance can be used to obtain

This article is protected by copyright. All rights reserved. 
information about cellular modifications of biological tissues during pretreatment and/or drying, considering that different subcellular compartments are characterized by specific water-solutes ratio ranges, leading to different transverse relaxation time $\left(\mathrm{T}_{2}\right)$ values. $^{41}$

The water mobility after pretreatment by immersion in assisted by PU application was studied by Rodriguez et al. ${ }^{24}$ in Granny Smith apple after the pretreatment and by Mothibe et $a l .{ }^{41}$ in Red Fuji apple before and during drying process $\left(70{ }^{\circ} \mathrm{C}\right)$. In the first case, compared with the raw sample, treaded ones exhibited longer $\mathrm{T}_{2}$ figures in all the compartments under study: cell wall, cytoplasm and vacuole. During the pretreatment, a water movement from the vacuole to the cytoplasm was observed because of the structural changes. This effect was more noticeable when PU $\left(2.1\right.$ and $\left.12.9 \mathrm{~kW} \mathrm{~cm}^{-2}\right)$ was applied during soaking, besides significant both water intake and solute transfer to the soaking medium. The authors concluded that these increments in mass transfer were due to the modification of the original cellular organization and subcellular structures of the vegetal tissue promoted by ultrasound. In the second case, after 5-15 min of acoustically treatment $(200 \mathrm{~W})$ the water intake and its free character inside the tissue led to longer $\mathrm{T}_{2}$ figures. During drying, the $\mathrm{T}_{2}$ figures in all cellular compartments decreased, specially the one corresponding to the vacuole compartment, which suggests that most of the water loss was removed from this compartment which is related to the volume shrinkage of the whole cell.

\section{COLOR}

The color change in a food product may affect the overall acceptability of the product by the consumers, therefore it should be considered when designing a drying process. ${ }^{18,80} \mathrm{In}$ the CIELab uniform color space, $\mathrm{L}^{*}$ indicates lightness, $\mathrm{a}^{*}$ is the chromaticity on a green $(-)$ and red $(+)$ axis and $\mathrm{b}^{*}$ is the chromaticity on a blue $(-)$ and yellow $(+)$ axis. These three parameters are included in the estimation of the color difference $\Delta E$ to the raw sample. $\Delta E$ figures higher than 2.0 might lead to noticeable differences in the visual perception of consumers. ${ }^{81}$

Different trends were observed regarding the effect of PU on the color of food products when applied as pretreatment. Kek et al. ${ }^{19}$ reported that sonicated $(20 \mathrm{kHz}, 400 \mathrm{~W})$ guavas immersed in either 35 or $70^{\circ}$ Brix solutions at $30^{\circ} \mathrm{C}$ were darker and greener than the raw ones (whitish green) and $\Delta E$ figures of 3.0 and 6.0 were observed. Fijalkowska et al. ${ }^{34}$

This article is protected by copyright. All rights reserved. 
reported that ultrasonic pretreatment modified the color of the apple tissue (var. Idared). In this study, using ultrasonic baths, at an ultrasound frequency of $21 \mathrm{kHz}\left(3 \mathrm{~W} \mathrm{~cm}^{-2}\right)$, the $\mathrm{L}^{*}, \mathrm{a}^{*}$, and $\mathrm{b}^{*}$ figures increased; however, at a frequency of $35 \mathrm{kHz}\left(4 \mathrm{~W} \mathrm{~cm}{ }^{-2}\right)$ the opposite outcome was observed. The $\Delta E$ figure of the non-sonicated samples was of 3.7 , while for sonicated apples it was of $6.0\left(3 \mathrm{~W} \mathrm{~cm}^{-2}\right)$ and $3.6\left(4 \mathrm{~W} \mathrm{~cm}^{-2}\right)$. Similar findings were reported by Rawson et al. ${ }^{42}$ in carrots. In this study, after $3-10$ min treatment using distilled water at $25^{\circ} \mathrm{C}$ and acoustic assistance by means of an ultrasonic probe $(78-190$ $\mathrm{W})$, samples dried at $60{ }^{\circ} \mathrm{C}$ exhibited a $\Delta E$ figure between 9.5 and 10.0 , while blanched samples without acoustic assistance exhibited a $\Delta E$ figure lower than 7.5.

The PU application $(35 \mathrm{kHz}, 480 \mathrm{~W})$ during the pretreatment of mushrooms using distilled water $\left(30 \mathrm{~min}, 30^{\circ} \mathrm{C}\right.$ ) was studied by Çakmak et al. ${ }^{39}$ The $\Delta E$ figure of dried samples $\left(50^{\circ} \mathrm{C}\right)$ decreased from 22.1 (no sonicated) to 3.36 (sonicated). Mothibe et al. ${ }^{41}$ reported that after drying at $70{ }^{\circ} \mathrm{C}$, L figures in ultrasonically treated apples, tended to decrease with increasing exposure time to ultrasonic waves $(25 \mathrm{kHz}, 200 \mathrm{~W})$. This might be because ultrasound destruction of cells might have released enzymes responsible for browning to the surface leading to dark color. In convective drying of melon at $60{ }^{\circ} \mathrm{C}$, acoustically pretreated $\left(25 \mathrm{kHz}, 4780 \mathrm{~W} \mathrm{~m}^{-2}\right)$ samples using distilled water led to brighter (lower $\mathrm{L}^{*}$ figures) samples than those dried without pretreatment; however, regarding the $\Delta E$ figure no significate differences were observed between them. ${ }^{45}$ Stojanovic et al. ${ }^{36}$ studied the effect of the sonication $(850 \mathrm{kHz}, 100 \mathrm{~W})$ on the color change in blueberry using a $55^{\circ}$ Brix solution at $21^{\circ} \mathrm{C}$ during $3 \mathrm{~h}$, followed by a convective drying at $70{ }^{\circ} \mathrm{C}$ during $10 \mathrm{~h}$. They reported $\Delta E$ figures lower than 2.0 before drying and around 6.0 after drying. However, no significant effect of the PU application was observed.

The change of color has been related to the degradation of biocompounds during processing. For instance, osmotic dehydration ( 40 and $60 \%$ fructose for $2 \mathrm{~h}$ at $25{ }^{\circ} \mathrm{C}$ ) of carrot promoted a very negative effect in the color of the dried product (30 min of heating at $70{ }^{\circ} \mathrm{C}, 5 \mathrm{~min}$ of cooling at $21{ }^{\circ} \mathrm{C}$ ) being the $\Delta \mathrm{E}$ figure of 14.4 ; however, when the osmotic dehydration was ultrasonically assisted $(38 \mathrm{kHz}, 320 \mathrm{~W})$ the $\Delta E$ figure was lower (9.0). This situation was related to a higher preservation of carotenoid compounds. ${ }^{48}$

Kowalski et al..$^{82}$ reported that the dying $\left(60{ }^{\circ} \mathrm{C}\right)$ of cherries led to a degradation of anthocyanins revealed as a color change (red color) by a decrease of $\mathrm{L}^{*}$ and $\mathrm{a}^{*}$ parameters.

This article is protected by copyright. All rights reserved. 
In this study, cherries were osmotically dehydrated (60 ${ }^{\circ}$ Brix solution, $\left.25{ }^{\circ} \mathrm{C}, 30 \mathrm{~min}\right)$ without and with acoustic assistance $(25 \mathrm{kHz}, 700 \mathrm{~W})$. The $\Delta E$ figure of dried cherries was of 16.0, 12.0 and 10.0 for those dried without pretreatment, osmotically treated without and with acoustic assistance, respectively. According to Sledz et al. ${ }^{44}$ the green color (negative figures of $\mathrm{a}^{*}$ ) in parsley leaves is an expression of both the chlorophyll $a$ and $b$ contents. The parameter $\mathrm{a}^{*}$ in fresh samples was of -13.7 , and it increased to -12.8 and -9.6 in dried leaves without and with ultrasonic assisted pretreatment by immersion in distilled water at $22{ }^{\circ} \mathrm{C}$ during $20 \mathrm{~min}$ in an ultrasonic bath $(21 \mathrm{kHz}, 300 \mathrm{~W})$ and convectively dried at $20-40 \mathrm{C}$ with microwave assistance $(100-300 \mathrm{~W})$ which means a less green product. However, the $\Delta E$ figure did not exceed the values of 2.0 when PU was applied and the convective drying was assisted by microwave (100W) at 20 and 30 ${ }^{\circ} \mathrm{C}$.

In freeze drying red bell pepper at $-30^{\circ} \mathrm{C}$, no differences between dried samples with and without ultrasonic assistance $(76-110 \mathrm{~W})$ were reported by Schössler et al. ${ }^{61}$ However, Szadzinska et al. in drying of strawberry ${ }^{73}$ and green pepper ${ }^{74}$ at 54 and $52{ }^{\circ} \mathrm{C}$, respectively, without and with acoustic assistance $(100-200 \mathrm{~W})$ found that convective drying assisted by PU promoted lower $\Delta E$ figures. Conventionally dried strawberry and green pepper samples exhibited a $\Delta E$ figure of 22.0 and 15.1, respectively; while those dried with acoustic assistance exhibited $\Delta E$ figures of 12.0 and 11.5, respectively. Similar findings were observed in the drying of raspberries carried out at $70{ }^{\circ} \mathrm{C}$. The PU application reduced the $\Delta E$ figure from 16.5 (not assisted) to 14.5 and 12.5 when an ultrasonic intensity of $100 \mathrm{~W}$ and $200 \mathrm{~W}$ were used. ${ }^{58}$ This improvement was justified with the intensification of the drying process, and therefore the shorter exposition to the thermal treatment.

\section{ANTIOXIDANT ACTIVITY}

The compounds with multiple biological effects presented in fruit, vegetables and plant extract corresponded mainly to vitamins $\mathrm{C}$ and $\mathrm{E}$, polyphenols, carotenoids and compounds of the Maillard reaction. The major property of them is their radicalscavenging capacity, which is involved in their antioxidant properties. ${ }^{83}$ The knowledge of the antioxidant activity of food products and the effects of processing conditions on it allows to determine the protection against oxidation and the deterioration of the food that diminishes its quality and nutritional value. The effect of sonication as pretreatment on

This article is protected by copyright. All rights reserved. 
the antioxidant activity (AA) depends on the product considered. Romero et al. ${ }^{22}$ reported that the sonication $\left(24 \mathrm{kHz}, 38-76 \mathrm{~W} \mathrm{~cm}^{-3}\right)$ applied on blackberry using distilled water at $15{ }^{\circ} \mathrm{C}$ during $10-30$ min promoted a significant reduction of the AA (FRAP assay). Without sonication, samples exhibited a reduction of 5\% during the treatment while the application of acoustic energy promoted a reduction up to $90 \%\left(30 \mathrm{~min}, 76 \mathrm{~W} \mathrm{~cm}^{-3}\right)$. In this study, the increase of the acoustic intensity applied was more harmful than the sonication time. Stojankovic et al. ${ }^{36}$ reported that the osmodehydration (3 and 12h, 55 ${ }^{\circ}$ Brix) of blueberry samples promoted a reduction of $50 \%$ in the AA (DPPH assay) compared with the fresh sample (30\%), however no effect of the PU assistance was observed. After drying $\left(10 \mathrm{~h}, 70{ }^{\circ} \mathrm{C}\right)$ the reduction of the AA was higher than $50 \%$.

A positive effect of sonication carried out at 75,226 and $373 \mathrm{~W} \mathrm{~cm}^{-2}$ on the AA of cashew bagasse was found by Fonteles et al. ${ }^{75}$ According to these authors, the acoustic treatment during 2-10 min promoted a raise of the AA from 275 (untreated) to $500-650 \mu \mathrm{mol}$ Trolox $\mathrm{g}^{-1}$ before the drying process, this could be related to the cell disruption and the release of the intracellular content. During the convective drying at $60{ }^{\circ} \mathrm{C}$, the AA of treated sample increased with the drying time up to $600-700 \mu \mathrm{mol}$ Trolox $\mathrm{g}^{-1}$. However, the AA of the untreated sample decreased below $200 \mu$ mol Trolox $\mathrm{g}^{-1}$. The authors attributed this result to the formation of new compounds with higher antioxidant activity due to, for example, the Maillard reaction, which creates several products with markedly higher antioxidant activity.

The sonication of mulberry leaves, using an ultrasonic probe $\left(63.0 \mathrm{~W} \mathrm{~L}^{-1}\right)$ during $10 \mathrm{~min}$ before convective drying at $60{ }^{\circ} \mathrm{C}$ promoted a slight increment of $6.9 \%$ of the AA measured by FRAP assay compared to the untreated dried sample; nevertheless, no significant differences were observed regarding the AA measured by ABTS assay among untreated, treated without and with sonication samples. ${ }^{43}$ According to these authors, although the acoustic pretreatment led to a solid loss, the reduction in drying time promoted could alleviate the damage caused by thermal energy, therefore, conserving of the AA in the dried product.

Rodriguez et al..$^{33}$ studied the effect of sonication $\left(25 \mathrm{kHz}, 5.1 \mathrm{~W} \mathrm{~L}^{-1}\right)$ in pineapple using distilled water at $30{ }^{\circ} \mathrm{C}$ during $10-30 \mathrm{~min}$. Compared with the fresh sample, the AA of sonicated samples measured by DPPH assay was between 20 and 30\% higher, while non-

This article is protected by copyright. All rights reserved. 
sonicated ones exhibited a slight reduction near to $10 \%$. The AA measured by FRAP assay was lower in all treated samples. In this case, the longer acoustic application the higher AA loss, up to $50 \%$ after $30 \mathrm{~min}$ of sonication. After drying at $60{ }^{\circ} \mathrm{C}$, only sonicated samples exhibited an increase between 37 and $57 \%$ of the AA measured by DPPH assay. Regarding the AA measured by FRAP assay, drying promoted a loss of the AA; nevertheless, all dried samples exhibited a higher AA figure than the one observed in the untreated dried sample.

The effect of PU application during convective drying of Granny smith apple has been studied by Rodriguez et al. ${ }^{64}$ and Santacalina et al. ${ }^{65}$ In the first study, using hot air (30 $\left.70{ }^{\circ} \mathrm{C}\right)$ the higher the acoustic intensity applied $\left(30.8 \mathrm{~kW} \mathrm{~m}^{-3}\right)$, the better retention of the AA (ABTS, FRAP assays) at a drying temperature of $30{ }^{\circ} \mathrm{C}$, however when a drying temperature of $70{ }^{\circ} \mathrm{C}$ was used the PU application promoted a higher degradation of the AA. In the second study, when low drying temperatures were used $\left(-10-10{ }^{\circ} \mathrm{C}\right)$ the PU application $\left(20.5 \mathrm{~kW} \mathrm{~m}^{-3}\right)$ involved a greater degradation of the AA (CUPRAC; ABTS; FRAP; DPPH assays) which was linked to the cell disruption under acoustic stress. The effect of the acoustic intensity applied $(25,50$ and $75 \mathrm{~W})$ on the AA was studied by Santacatalina et al..$^{23}$ during the low temperature drying $\left(10\right.$ and $\left.-10^{\circ} \mathrm{C}\right)$ of Granny Smith apple. According to the authors, regardless the acoustic intensity used, the AA (FRAP assay) degradation ranged between 46 and 76\%. At intermediate acoustic intensities (25 and $50 \mathrm{~W}$ ) the AA loss was higher at $-10{ }^{\circ} \mathrm{C}$ than at $10{ }^{\circ} \mathrm{C}$, however, at 0 and $75 \mathrm{~W}$ the differences were not significant.

In drying grape skin at different temperatures $\left(40,50,60\right.$ and $\left.70{ }^{\circ} \mathrm{C}\right)$ the acoustic assistance of $45 \mathrm{~W}$, promoted a decrease in the AA (FRAP assay) of dried samples regardless the drying temperature. ${ }^{71}$ This degradation could not be related to any heating effect from the acoustic energy; however, ultrasound could provoke severe structural modifications, degrading cell wall components and making the enzyme release and so the phenolic oxidation easier. ${ }^{68}$ do Nascimento et $a l .{ }^{72}$ studied the effect of the PU application $\left(30.8 \mathrm{~kW} \mathrm{~m}^{-3}\right)$ on the AA (FRAP assay) during the drying of passion fruit peel at $40,50,60$ and $70^{\circ} \mathrm{C}$. In this study, the influence of the acoustic assistance was different at each temperature. Thus, at 40 and $50{ }^{\circ} \mathrm{C}$, the AA was similar to the fresh sample $(15.2$ $\mu \mathrm{mol}$ Trolox/g d.m.), but at 60 and $70{ }^{\circ} \mathrm{C}$, the average AA was $40 \%$ lower than the fresh sample. The application of PU, on one hand, reduced the drying time and then limited the

This article is protected by copyright. All rights reserved. 
oxidation reactions which maintain the AA when is applied at lower temperatures. On the other hand, it affected negatively the AA when applied at higher temperatures due to a negative synergy effect of thermal and acoustic energy.

\section{BIOACTIVE COMPOUNDS}

The PU applied as pretreatment or during convective drying may shorten the drying time, thus favoring the bioactive compound retention which is highly beneficial for the final quality of the dried product. ${ }^{37}$

Plants produce an extraordinary diversity of phenolic compounds which are excellent oxygen radical scavengers. ${ }^{84}$ In general, studies carried out in blueberry, ${ }^{36}$ cherry, ${ }^{37}$ mushroom, ${ }^{39}$ and carrot ${ }^{85}$ reported that the PU application as pretreatment before drying produced a reduction of the total phenolic content (TPC) of treated samples, mostly attributed to the leakage of phenolic compounds through the vegetal tissue during the pretreatment. Similar results were reported by Rodriguez et al. ${ }^{33}$ in the acoustically assisted pretreatment $\left(25 \mathrm{kHz}, 5.1 \mathrm{~W} \mathrm{~L}^{-1}\right)$ of pineapples using distilled water at $30{ }^{\circ} \mathrm{C}$ during $10-30 \mathrm{~min}$. A reduction of $40-60 \%$ of TPC was observed in sonicated samples. However, after drying $\left(60^{\circ} \mathrm{C}\right)$ the TPC increased, so the final loss was only between 10 and $25 \%$. This increment can possibly be explained by the release of more bound phenolic compounds from the breakdown of cellular constituents during the drying that did not migrate during the pretreatment.

When convective drying was acoustically assisted, the PU application (18.5 and $30.8 \mathrm{~kW}$ $\mathrm{m}^{-3}$ ) allowed a better preservation of phenolic compounds in apple $\mathrm{e}^{64}$ and passion fruit $\operatorname{peel}^{72}$ when lower temperatures were used $\left(30\right.$ and $\left.40{ }^{\circ} \mathrm{C}\right)$, but when higher temperatures were used $\left(50\right.$ and $\left.70^{\circ} \mathrm{C}\right)$ the ultrasonic assistance promoted a higher degradation of these compounds. Cruz et al. ${ }^{71}$ reported that TPC were more sensitive to ultrasound application (45 W), since acoustically assisted dried samples exhibited a TPC $18.4 \%$ and $31.0 \%$ lower than the non-assisted samples. A negative effect of PU $\left(20.5 \mathrm{~kW} \mathrm{~m}^{-3}\right)$ application was also observed during the freeze drying $\left(-10-10^{\circ} \mathrm{C}\right)$ of apple. ${ }^{65}$ The average loss of was significantly higher (41\%) in samples acoustically assisted than the one found in nonultrasonically assisted samples (31\%) at every temperature tested. This fact could be linked to the structural damage of cells brought about by ultrasound

This article is protected by copyright. All rights reserved. 
Carotenoids determine the color and the nutritional quality of many dried fruits and vegetables. They are very stable in the fresh tissue but unstable by the action of heat, light and oxygen, The carotenoid content has been measured in papaya, ${ }^{40} \operatorname{carrot}^{42}$ and melon $^{45}$ when PU was applied during pretreatment. Azoubel et al. ${ }^{40}$ pretreated papaya slices using a distilled water or a sucrose solution $\left(56^{\circ}\right.$ Brix) at $34{ }^{\circ} \mathrm{C}$ during $10-30 \mathrm{~min}$. The ultrasound frequency was $25 \mathrm{kHz}$, and the intensity was $4870 \mathrm{~W} \mathrm{~m}^{-2}$. After drying (70 ${ }^{\circ} \mathrm{C}$ ) the carotenoid loss in untreated samples was of $76 \%$; however, in acoustically treated samples immersed in water the loss ranged between 60 and $69 \%$ and still, the loss was lower and ranged between 35 and $54 \%$ in samples immersed in sucrose solution. According to the authors, a sugar barrier layer can be located at the sample's surface when using osmotic solutions that limited the contact between the fruit and the oxygen during drying, reducing carotenoid oxidation. Similarly, Dias da Silva et al. ${ }^{45}$ applied PU (4870 $\left.\mathrm{W} \mathrm{m}^{-2}\right)$ on melon slices using distilled water or sucrose solution (50 ${ }^{\circ}$ Brix) during $10-$ 30 min at $30{ }^{\circ} \mathrm{C}$. After drying $\left(60^{\circ} \mathrm{C}\right)$, untreated sample lost up to $95 \%$ of the carotenoid content, and a similar loss was observed in acoustically treated sample, being the loss of 96 and 94 when samples were immersed in distilled water and osmotic solution, respectively. Rawson et al. ${ }^{42}$ applied PU $(78-190 \mathrm{~W})$ on carrot disks immersed in distilled water at $25^{\circ} \mathrm{C}$. After drying $\left(60^{\circ} \mathrm{C}\right)$ the carotenoid retention in samples acoustically treated during 3 min ranged between 65 and $83 \%$, and between 65 and $75 \%$ after 10 min of acoustic treatment, while the untreated sample exhibited a $73 \%$ retention. After freeze drying $\left(0^{\circ} \mathrm{C}\right)$, the carotenoid retention in samples acoustically treated during 3 min ranged between 95 and 100\%, and between 98 and 106\% after 10 min of acoustic treatment, while the untreated conserved the integral carotenoid content.

In the convective drying of carrots at 20,40 and $60{ }^{\circ} \mathrm{C}$, Frias et al. ${ }^{57}$ reported that the PU application $(100 \mathrm{~W})$ promoted a slight reduction $(<3 \%)$ of the $\beta$-carotene content compared to the fresh sample and no differences were observed among the three temperatures used. (No data of the sample dried without acoustic assistance). Fernandes et al ${ }^{67}$ reported that, in general, when PU was applied $(21 \mathrm{kHz}, 75 \mathrm{~W})$ during the drying (45 and $60{ }^{\circ} \mathrm{C} ; 1-3 \mathrm{~m} \mathrm{~s}^{-1}$ ) of cherry tomato it was observed an increment in the lycopene and carotenoid content of 2 and $12 \%$, respectively when drying was carried out at $45^{\circ} \mathrm{C}$ and $1 \mathrm{~m} \mathrm{~s}^{-1}$; in contrast with the non-ultrasonically assisted dried sample which exhibited losses of 44 and $31 \%$ of both biocompounds under the same drying conditions. In general,

This article is protected by copyright. All rights reserved. 
for the others drying experiments, samples exhibited losses of both biocompounds, however the loss was lower in the acoustically assisted dried one.

Berries and cherries are well known by their anthocyanin content and its strong antioxidant and anti-inflammatory activities. ${ }^{82}$ Stojanovic et al. ${ }^{36}$ reported a negative effect of the PU application $(850 \mathrm{kHz}, 100 \mathrm{~W})$ in osmotic conditions in berry. After treatment, the loss of anthocyanin content was of $50 \%$ and after drying it reached $82 \%$, while the untreated sample exhibited a loss of $68 \%$ after drying. Similarly, in drying cherry, Siucinska et al. ${ }^{37}$ found that the PU application in osmotic conditions promoted a reduction of $30-48 \%$ before drying, and it increased to $50-67 \%$ after drying. The highest retention was observed when cherries were osmodehydrated up to $60 \mathrm{~min}$, longer pretreatment times promoted a higher degradation.

The chlorophyll content of parsley and mulberry leaves has been considered as quality parameter by Sledz et al. ${ }^{44}$ and Tao et al. ${ }^{43}$ In the first case, the pretreatment of parsley leaves was carried out with an ultrasonic power of $300 \mathrm{~W}$ using distilled water at $22{ }^{\circ} \mathrm{C}$ during $20 \mathrm{~min}$. Convective drying was carried out at 20,30 and $40{ }^{\circ} \mathrm{C}$ without and with microwave assistance (100 and $300 \mathrm{~W})$. According to these authors, acoustically treated samples exhibited a higher chlorophyll retention (60 and $80 \%$ ) than non-treated one (58 and $65 \%$ ) when the drying was carried out at $20{ }^{\circ} \mathrm{C}$ and assisted with 100 and $300 \mathrm{~W}$. In the second case, mulberry leaves were treated with 25.2, 63.0 and $117.6 \mathrm{~W} \mathrm{~L}^{-1}$ using distilled water during $5-15 \mathrm{~min}$. After drying $\left(60{ }^{\circ} \mathrm{C}\right)$, the chlorophyll content of untreated sample was of $2.4 \mathrm{~g} \mathrm{~g}^{-1}$, and the treatment promoted a slight increment of $9 \%$ in both treated samples.

\section{VITAMINS CONTENT}

Regarding vitamin C, Kek et al. ${ }^{19}$ reported that after drying, the acoustically treated guavas under osmotic conditions exhibited the lowest vitamin content and it was $4-17 \%$ lower than the untreated sample, however with a $70^{\circ}$ Brix solution, the reduction was less which might be related to a lesser cavitation effect produced in viscous liquids. The sonication induced an increment in the vitamin $\mathrm{C}$ content of cashew apple bagasse, and it was justified due to the cell disruption and the release of the intracellular content. After drying, a reduction of the vitamin $\mathrm{C}$ content was observed, however, sonicated samples exhibited a higher final content (6 times) than untreated ones. ${ }^{75}$ In pineapple, the

This article is protected by copyright. All rights reserved. 
sonication promoted a reduction of this vitamin ranged between $15-40 \%$, possibly related to the leakage of solids into the soaking medium; however, after drying, the final vitamin $C$ content of treated samples was higher $(250-275 \%)$ than the untreated one. The reduction of the drying time and thus, the time exposed to high temperature is one of the main factors towards reducing the loss of vitamin C. ${ }^{33}$ Frías et al. ${ }^{57}$ reported retention figures of $82-92 \%$ when blanched carrot were acoustically dried $(100 \mathrm{~W})$ while a retention lower than $50 \%$ was observed in not acoustically dried samples. ${ }^{51}$ Szadzinska et al. ${ }^{74}$ reported retention figures of $62-69 \%$ in acoustically treated $(100-200 \mathrm{~W})$ samples and $42 \%$ in not assisted ones. In strawberry, compared to the not assisted sample, the vitamin $\mathrm{C}$ retention $(\sim 65 \%)$ was lower in samples acoustically $(30,60 \mathrm{~W})$ dried at higher temperature $\left(50-70{ }^{\circ} \mathrm{C}\right)$. In this case, the combination of thermal and acoustic energy was negative possibly because the PU application could facilitate the air penetration in the sample which eases the oxidation of the ascorbic acid.

Thiamin $\left(\mathrm{B}_{1}\right)$, riboflavin $\left(\mathrm{B}_{2}\right)$, niacin $\left(\mathrm{B}_{3}\right)$, pantothenic acid $\left(\mathrm{B}_{5}\right)$, pyridoxine $\left(\mathrm{B}_{6}\right)$ belong to the water-soluble B vitamins and the effect of the PU application on them has been studied by Rodriguez et al. ${ }^{33}$ in pineapple and Fernanes et al. ${ }^{1,67}$ in apple and cherry tomato. In the first case, when PU was applied as pretreatment $\left(25 \mathrm{kHz}, 5.1 \mathrm{~W} \mathrm{~L}^{-1}\right)$, the acoustic energy promoted a noticeable increment in all B vitamins between 250 and $600 \%$ before drying, as consequence of the disruption of the chemical bounding between vitamins and their coenzymes. However, the drying process $\left(50^{\circ} \mathrm{C}\right)$ promoted a dramatic reduction of these vitamins due to their thermolability, and the final amount was like the one of the untreated dried sample. In drying apple and cherry tomato, the influence of the PU application was more noticeable at low air velocities and drying temperatures. The application of ultrasound could help increasing the availability of the free form of vitamins $\mathrm{B}_{1}+\mathrm{B}_{2}, \mathrm{~B}_{3}$, and $\mathrm{B}_{6}$, releasing the vitamin from its bound to membrane, protein, or apoenzyme. Degradation of vitamin $B_{5}$ was observed (only in apple) possibly because it was presented in its free form.

The degradation of lipid-soluble vitamins during drying have been studied in apple (vitamins A and E) ${ }^{1}$ and in cherry tomato (vitamin E) ${ }^{67}$ In apple, PU application $(21 \mathrm{kHz}$, $75 \mathrm{~W})$ promoted and increment of the vitamin A when air velocities of $2(50 \%), 3(100 \%)$ were used at $60{ }^{\circ} \mathrm{C}$, but losses were observed when air velocities of $1(20 \%)$ and $2 \mathrm{~m} \mathrm{~s}^{-1}$ $(25 \%)$ were used at $45{ }^{\circ} \mathrm{C}$. The drying process promoted a reduction of the vitamin $\mathrm{E}$ 
ranged between 25 and $75 \%$ regardless the drying temperature or air velocity. Nevertheless, samples dried at $60{ }^{\circ} \mathrm{C}$ with acoustic assistance exhibited higher figures of vitamin E. Vitamin A is usually found associated with cell membrane and lipoproteins and its degradation may be linked to the reduction of vitamin $\mathrm{E}$, which plays a protective role. The radical scavenging behavior of vitamin E may play a role in its consumption during drying. Since the UP application induces the production of small quantity of free radicals, in the fruit matrix, that will be attacked by vitamin E. In cherry tomato, the acoustic assistance $(21 \mathrm{kHz}, 75 \mathrm{~W})$ promoted an increment of the vitamin E content only at $45{ }^{\circ} \mathrm{C}$ and $1(141 \%)$ and $2 \mathrm{~m} \mathrm{~s}^{-1}(102 \%)$, in the other conditions under study, the retention of the vitamin E ranged between 63 and 97\% while the not assisted sample exhibited figures between 66 and 104\%. Compared with apple, the higher retention if vitamin $\mathrm{E}$ in cherry tomato might be related to the lycopene content in tomato, which is more prone to degradation by free radicals and hydrogen peroxide than vitamin $\mathrm{E}$.

\section{ENZYMATIC ACTIVITY}

In cashew apple bagasse, Fonteles et al. ${ }^{75}$ studied the effect of the PU application as pretreatment on ascorbate peroxidase (APX), peroxidase (POD) and polyphenol oxidase (PPO). The sonication promoted only a significant inactivation $(75 \%)$ of the POD activity; that remain stable during the drying. Regarding the APX and PPO activities, sonicated samples exhibited a reduction of $12-20 \%$ and $20-30 \%$ respectively. Not sonicated sample exhibited higher enzymatic activities at the end of the drying process. Rodriguez et al. ${ }^{24}$ measured the PPO activity in apple after sonication. A reduction of 13 $-58 \%$ of the PPO enzyme activity was observed, being the best inhibitory results those obtained when citric acid was used as the soaking medium and the highest acoustic intensity was applied $\left(12.9 \mathrm{~W} \mathrm{~cm}^{-2}\right)$. In both cases, authors related the inhibitory effect with the intense pressures and shear forces generated by ultrasonic waves that denature the protein.

This article is protected by copyright. All rights reserved. 


\section{CONCLUSIONS}

This review meant to give a general outline of the research works covering the application of power ultrasound in the intensification of the drying of fruits and vegetables. All included papers covered the study of the effect of power ultrasound application on the different quality parameters of the food product, either when the application has been carried out as pretreatment before drying, or during the drying process itself. From the results obtained by various authors, the effects of ultrasound application on the product quality differed according to the system where it was applied: as pretreatment (liquid) or during drying (gas), the acoustic intensity applied, and mainly due to the nature of the food matrix.

According to the authors cited in this review, the application of power ultrasound as pretreatment by means of either ultrasonic baths or ultrasonic probes and using as liquid medium distilled water increase the reduction of the solid content together with the increment of the moisture content from. When osmotic solutions were used, the effect of the power ultrasound application was observed as the enhancement of the mass transport, increments in the solid content and reductions of the moisture content were observed in the treated products.

The transport of solids and water between sample and medium under the acoustic waves, promoted also the leakage of important biocompounds which affect mainly the appearance (color) and the nutritional quality of the treated and dried product. The sponge effect which affects the internal structure of the sample, promoting the movement of solids outside of the sample can be one of the main effects of ultrasound responsible of this. However, the acoustic energy applied during the pretreatment allowed the bond breakage between the cellular matrix and the strongly attached fraction of these biocompounds, so the leakage can be compensated by the release of this fraction. As a result, a higher bioavailability of these biocompounds was achieved. However, despite the higher bioavailability, the thermolabile character of these biocompounds together with the thermal energy given to the system during drying promoted a reduction of their content in the dried product. It is worthy of pointing out that in almost all cases the content of these biocompounds in dried acoustically treated products was higher than the one in non-treated dried products.

This article is protected by copyright. All rights reserved. 
The use of osmotic solutions during pretreatments was reported in few papers. The high viscosity of these solutions, diminished the cavitation effect produced by acoustic waves and then reduces the effects of ultrasound. On the contrary, after treatment a sugar barrier on the surface of the product could reduce contact between the product and the oxygen during drying, therefore less oxidation.

The application of power ultrasound during the convective drying affected in different levels the quality of the dried product and similarly to the application as pretreatment, that is, the effects varied according to the nature of the sample and the type of drying carried out. The application of PU, on one hand, promoted an intensification of the drying process and then limited the oxidation reactions which maintain most of the biocompounds intact when it was applied at lower temperatures. On the other hand, it affected negatively the biocompounds when it was applied at higher temperatures due to the synergy of thermal and acoustic energy.

Increments in the vitamins $\mathrm{B}_{1}, \mathrm{~B}_{2}, \mathrm{~B}_{3}$, and $\mathrm{B}_{6}$, availability after acoustically assisted drying were observed in few cases, but they corresponded to specific drying settings (air velocity and temperature, ultrasonic intensity), not being this positive effect observed under other different drying conditions. The increments were linked to higher detachment of these vitamins from its bound to the apoenzyme which was induced by the ultrasound application. The degradation of vitamins vitamin $\mathrm{C}, \mathrm{E}$ and $\mathrm{B} 5$ was related to their free character in the food matrix, which made them more susceptible to thermal and acoustic energy.

Regarding enzyme activity, acoustic assistance as pretreatment or during drying promoted a significant reduction of it due to denaturation of the enzyme protein.

The application of power ultrasound to intensify drying has been deeply studied by food technologist and it is still avid of more research focus on the optimization of the use of this technology in terms of the quality of the dried product. Effects are widely diverse among products under study, so major effort must be done to cover a widely variety of product and to take this technology from laboratory scale to industrial level.

This article is protected by copyright. All rights reserved. 


\section{AKNOWLEDGMENTS}

The authors would like to acknowledge Conselleria d'Agricultura, Medi Ambient $i$ Territori and Fons de Garantia Agrària i Pesquera de les Illes Balears (FOGAIBA), and the Spanish Government (MEIC) for the financial support (RTA2015-00060-C04, AIA01/15).

\section{REFERENCES}

1. Fernandes FAN., Rodrigues S, Cárcel JA and García-Pérez JV, Ultrasoundassisted air-drying of apple (Malus domestica L.) and its effects on the vitamin of the dried product. Food Bioprocess Tech 8: 1503-1511(2015).

2. Cárcel JA, García-Pérez JV; Riera E, Rosselló C and Mulet A, Drying Assisted by Power Ultrasound. In Modern Drying Technology, ed. Wiley-VCH Verlag GmbH \& Co. KGaA, pp. 237-278 (2014).

3. Bird B, Stewart W and Lightfoot E, Transport Phenomena. John Wiley \& Sons, Inc. (2006).

4. Ozuna C, Álvarez-Arenas TG, Riera E, Cárcel JA and Garcia-Perez JV, Influence of material structure on air-borne ultrasonic application in drying. Ultrason Sonochem 21: 1235-1243. (2014).

5. Venkatesh MS and Raghavan GSV, An overview of microwave processing and dielectric properties of agri-food materials. Biosyst Eng 88: 1-18 (2004).

6. Feng H, Yin Y and Tang J, Microwave drying of food and agricultural materials: basics and heat and mass transfer modeling. Food Eng Rev 4: 89-106 (2012).

7. Oey I, Lille M, Van Loey A and Hendrickx M, Effect of high-pressure processing on colour, texture and flavour of fruit- and vegetable-based food products: a review. Trends Food Sci Tech 19: 320-328 (2008).

8. Chen D, Xi H, Guo X, Qin Z, Pang X, Hu X, Liao X and Wu J, Comparative study of quality of cloudy pomegranate juice treated by high hydrostatic pressure and high temperature short time. Innov Food Sci Emerg 19: 85-94 (2013).

9. Landl A, Abadias M, Sárraga C, Viñas I and Picouet PA, Effect of high pressure processing on the quality of acidified Granny Smith apple purée product Innov Food Sci Emerg 11: 557-564 (2010).

10. Ade-Omowaye BIO, Angersbach A, Taiwo KA and Knorr D, Use of pulsed electric field pre-treatment to improve dehydration characteristics of plant based foods. Trends Food Sci Tech 12: 285-295 (2001).

11. Chemat F, Zill EH and Khan MK, Applications of ultrasound in food technology: Processing, preservation and extraction. Ultrason Sonochem 18: 813-835 (2011).

12. Fernandes FAN and Rodrigues S, Ultrasound as pre-treatment for drying of fruits: Dehydration of banana. J Food Eng 82: 261-267 (2007).

13. Cárcel JA, García-Pérez JV, Benedito J and Mulet A, Food process innovation through new technologies: Use of ultrasound. J Food Eng 110: 200-207 (2012).

14. Fernandes FAN, Linhares Jr. FE and Rodrigues S, Ultrasound as pre-treatment for drying of pineapple. Ultrason Sonochem 15: 1049-1054 (2008).

15. García-Pérez JV, Cárcel JA, Benedito J and Mulet A, Power ultrasound mass transfer enhancement on food drying. Food Bioprod Process 85: 247-254 (2007).

16. Mason TJ, Riera E, Vercet A and Lopez-Buesa P, Application of Ultrasound, in Emerging Technologies for Food Processing, Sun, D.-W., Ed. Academic Press: London, pp. 323-351 (2005).

This article is protected by copyright. All rights reserved. 
17. Soria AC and Villamiel M, Effect of ultrasound on the technological properties and bioactivity of food: a review. Trends Food Sci Tech 21: 323-331 (2010).

18. Pingret D, Fabiano-Tixier A-S and Chemat F, Degradation during application of ultrasound in food processing: A review. Food Control 31: 593-606 (2013).

19. Kek SP, Chin NL and Yusof YA, Direct and indirect power ultrasound assisted pre-osmotic treatments in convective drying of guava slices. Food Bioprod Process 91: 495-506 (2013).

20. Ricce C, Rojas ML, Miano AC, Siche R and Augusto, PED, Ultrasound pretreatment enhances the carrot drying and rehydration. Food Res Int 89: 701-708 (2016).

21. Gamboa-Santos J, Montilla A, Soria AC and Villamiel M, Effects of conventional and ultrasound blanching on enzyme inactivation and carbohydrate content of carrots. Eur Food Res Technol 234: 1071-1079 (2012).

22. Romero JCA and Yépez VBD, Ultrasound as pretreatment to convective drying of Andean blackberry (Rubus glaucus Benth). Ultrason Sonochem 22: 205-210 (2015).

23. Santacatalina JV, Contreras M, Simal S, Cárcel JA and Garcia-Perez JV, Impact of applied ultrasonic power on the low temperature drying of apple. Ultrason Sonochem 28: 100-109 (2016).

24. Rodríguez Ó, Llabrés P, Simal S, Femenia, A and Rosselló C, Intensification of predrying treatments by means of ultrasonic assistance: effects on water mobility, PPO activity, microstructure, and drying kinetics of apple. Food Bioprocess Tech 8: 503-515 (2015).

25. Jambrak AR, Mason TJ, Paniwnyk L and Lelas V., Accelerated drying of button mushrooms, Brussels sprouts and cauliflower by applying power ultrasound and its rehydration properties. J Food Eng 81: 88-97 (2007).

26. Fernandes FAN, Gallão MI and Rodrigues S., Effect of osmotic dehydration and ultrasound pre-treatment on cell structure: Melon dehydration. LWT-Food Sci Tech 41: 604-610 (2008).

27. Beck SM, Sabarez H, Gaukel V and Knoerzer K, Enhancement of convective drying by application of airborne ultrasound - A response surface approach. Ultrason Sonochem 21: 2144-2150 (2014).

28. Yao Y, Enhancement of mass transfer by ultrasound: Application to adsorbent regeneration and food drying/dehydration. Ultrason Sonochem 31: 512-531 (2016).

29. Oladejo AO and Ma H, Optimisation of ultrasound-assisted osmotic dehydration of sweet potato (Ipomea batatas) using response surface methodology. J Sci Food Agr 96: 3688-3693 (2016).

30. Santos HM, Lodeiro C, Capelo-Martínez J-L, The Power of Ultrasound, in Ultrasound in Chemistry, Wiley-VCH Verlag GmbH \& Co. KGaA, pp. 1-16 (2009).

31. Fernandes FAN and Rodrigues S, Osmotic Dehydration and Blanching, in Ultrasound in Food Processing, John Wiley \& Sons, Ltd, pp. 311-328 (2017).

32. Azoubel PM, Baima MdAM, Amorim MdR and Oliveira SSB, Effect of ultrasound on banana cv Pacovan drying kinetics. J Food Eng 97: 194-198 (2010).

33. Rodríguez Ó, Gomes W, Rodrigues S and Fernandes FAN, Effect of acoustically assisted treatments on vitamins, antioxidant activity, organic acids and drying kinetics of pineapple. Ultrason Sonochem 35: 92-102 (2017).

34. Fijalkowska A, Nowacka M, Wiktor A, Sledz M and Witrowa-Rajchert D, Ultrasound as a pretreatment method to improve drying kinetics and sensory properties of dried apple. J Food Process Eng 39: 256-265 (2016).

35. Nowacka M, Wiktor A, Śledź M, Jurek N and Witrowa-Rajchert D, Drying of ultrasound pretreated apple and its selected physical properties. J Food Eng 113: 427-433 (2012).

This article is protected by copyright. All rights reserved. 
36. Stojanovic J and Silva JL, Influence of osmotic concentration, continuous high frequency ultrasound and dehydration on antioxidants, colour and chemical properties of rabbiteye blueberries. Food Chem 101: 898-906 (2007).

37. Siucińska K, Mieszczakowska-Frąc M, Połubok A and Konopacka D, Effects of Ultrasound Assistance on Dehydration Processes and Bioactive Component Retention of Osmo-Dried Sour Cherries. J Food Sci 81: 1654-1661 (2016).

38. Oliveira FIP, Gallão MI, Rodrigues S and Fernandes FAN, Dehydration of malay apple (Syzygium malaccense 1.) using ultrasound as pre-treatment. Food Bioprocess Tech 4: 610-615 (2011).

39. Çakmak RŞ, Tekeoğlu O, Bozkır H, Ergün AR and Baysal T, Effects of electrical and sonication pretreatments on the drying rate and quality of mushrooms. LWT-Food Sci Tech 69: 197-202 (2016).

40. Azoubel PM, da Rocha Amorim M, Oliveira, SSB, Maciel MIS and Rodrigues JD, Improvement of water transport and carotenoid retention during drying of papaya by applying ultrasonic osmotic pretreatment. Food Eng Rev 7: 185 -192 (2015).

41. Mothibe KJ, Zhang M, Mujumdar AS, Wang YC and Cheng X, Effects of ultrasound and microwave pretreatments of apple before spouted bed drying on rate of dehydration and physical properties. Dry Technol 32: 1848-1856 (2014).

42. Rawson A, Tiwari BK, Tuohy MG, O'Donnell CP and Brunton N, Effect of ultrasound and blanching pretreatments on polyacetylene and carotenoid content of hot air and freeze dried carrot discs. Ultrason Sonochem 18: 1172-1179 (2011).

43. Tao Y, Wang P, Wang Y, Kadam SU, Han Y, Wang J and Zhou J, Power ultrasound as a pretreatment to convective drying of mulberry (Morus alba L.) leaves: Impact on drying kinetics and selected quality properties. Ultrason Sonochem 31: 310318 (2016).

44. Sledz M, Wiktor A, Rybak K, Nowacka M and Witrowa-Rajchert D, The impact of ultrasound and steam blanching pre-treatments on the drying kinetics, energy consumption and selected properties of parsley leaves. Appl Acous 103: 148-156 (2016). 45. Dias da Silva G, Barros ZMP, de Medeiros RAB, de Carvalho CBO, Rupert Brandão SC and Azoubel PM, Pretreatments for melon drying implementing ultrasound and vacuum. $L W T$-Food Sci Tech 74: 114-119 (2016).

46. Cárcel JA, Benedito J, Rosselló C and Mulet A, Influence of ultrasound intensity on mass transfer in apple immersed in a sucrose solution. J Food Eng 78: 472-479 (2007). 47. Garcia-Noguera J, Oliveira FIP, Gallão MI, Weller CL; Rodrigues S and Fernandes FAN, Ultrasound-assisted osmotic dehydration of strawberries: effect of pretreatment time and ultrasonic frequency. Dry Techol 28: 294-303 (2010).

48. Kowalski SJ, Szadzińska J and Pawłowski A, Ultrasonic-assisted osmotic dehydration of carrot followed by convective drying with continuous and intermittent heating. Dry Techol 33: 1570-1580 (2015).

49. Fernandes FAN, Gallão MI and Rodrigues S, Effect of osmosis and ultrasound on pineapple cell tissue structure during dehydration. J Food Eng 90 186-190 (2009).

50. Cárcel JA. García-Pérez JV, Riera E, Rosselló C and Mulet A, Ultrasonically Assisted Drying, in Ultrasound in Food Processing, John Wiley \& Sons, Ltd, pp. 371391 (2017).

51. Gamboa-Santos J, Montilla A, Cárcel JA, Villamiel M and Garcia-Perez JV, Airborne ultrasound application in the convective drying of strawberry. J Food Eng 128: 132-139 (2014).

52. Kowalski SJ and Pawłowski A, Intensification of apple drying due to ultrasound enhancement. J Food Eng 156: 1-9 (2015).

This article is protected by copyright. All rights reserved. 
53. Sabarez HT, Gallego-Juarez JA and Riera E, Ultrasonic-assisted convective drying of apple slices. Dry Technol 30: 989-997 (2012).

54. Cárcel JA, García-Pérez JV, Riera E and Mulet A, Improvement of convective drying of carrot by applying power ultrasound-influence of mass load density. Dry Technol 29: 174-182 (2011).

55. Gallego-Juarez JA, High-power ultrasonic processing: Recent developments and prospective advances. Physcs Proc 3: 35-47 (2010).

56. Gallego-Juárez JA, Riera E, de la Fuente Blanco S, Rodríguez-Corral G, AcostaAparicio VM and Blanco A, Application of high-power ultrasound for dehydration of vegetables: Processes and devices. Dry Technol 25: 1893-1901 (2007).

57. Frias $J$, Peñas E, Ullate $M$ and Vidal-Valverde $C$, Influence of drying by convective air dryer or power ultrasound on the vitamin $\mathrm{c}$ and $\beta$-carotene content of carrots. J Agr Food Chem 58: 10539-10544 (2010).

58. Kowalski SJ, Pawłowski A, Szadzińska J, Łechtańska J and Stasia M, High power airborne ultrasound assist in combined drying of raspberries. Innov Food Sci Emerg 34: 225-233 (2016).

59. Schössler K, Thomas $\mathrm{T}$ and Knorr D, Modification of cell structure and mass transfer in potato tissue by contact ultrasound. Food Res Int 49: 425-431 (2012).

60. Schössler K, Jäger $\mathrm{H}$ and Knorr D, Effect of continuous and intermittent ultrasound on drying time and effective diffusivity during convective drying of apple and red bell pepper. J Food Eng 108: 103-110 (2012).

61. Schössler K, Jäger H and Knorr D, Novel contact ultrasound system for the accelerated freeze-drying of vegetables. Innov Food Sci Emerg 16: 113-120 (2012).

62. García-Pérez JV, Carcel JA, Mulet A, Riera E and Gallego-Juarez JA, Ultrasonic drying for food preservation. In Power Ultrasonics, Woodhead Publishing: Oxford, pp 875-910 (2015).

63. Garcia-Perez JV, Carcel JA, Riera E, Rosselló C and Mulet A, Intensification of low-temperature drying by using ultrasound. Dry Technol 30: 1199-1208 (2012).

64. Rodríguez Ó, Santacatalina JV, Simal S, Garcia-Perez JV, Femenia A and Rosselló C, Influence of power ultrasound application on drying kinetics of apple and its antioxidant and microstructural properties. J Food Eng 129: 21-29 (2014).

65. Santacatalina JV, Rodríguez O, Simal S, Cárcel JA, Mulet A and García-Pérez $\mathrm{JV}$, Ultrasonically enhanced low-temperature drying of apple: Influence on drying kinetics and antioxidant potential. J Food Eng 138: 35-44 (2014).

66. Ozuna C, Cárcel JA, García-Pérez JV and Mulet A, Improvement of water transport mechanisms during potato drying by applying ultrasound. J Sci Food Agr 94: 2511-2517 (2011).

67. Fernandes FAN, Rodrigues S, García-Pérez JV and Cárcel JA, Effects of ultrasound-assisted air drying on vitamins and carotenoids of cherry tomatoes. Dry Technol DOI: 10.1080/07373937.2015.1090445 (2015).

68. García-Pérez JV, Ortuño C, Puig A, Carcel JA and Perez-Munuera I, Enhancement of water transport and microstructural changes induced by high-intensity ultrasound application on orange peel drying. Food Bioprocess Tech 5: 2256-2265 (2012).

69. García-Pérez JV, Cárcel JA, Benedito J, Riera E and Mulet A, Drying of a low porosity product (carrot) as affected by power ultrasound. Defect Diffus Forum 273-276: 764-769 (2008).

70. Puig A, Perez-Munuera I, Carcel JA, Hernando I and Garcia-Perez JV, Moisture loss kinetics and microstructural changes in eggplant (Solanum melongena L.) during

This article is protected by copyright. All rights reserved. 
conventional and ultrasonically assisted convective drying. Food Bioprod Process 90: 624-632 (2012).

71. Cruz L, Clemente G, Mulet A, Ahmad-Qasem MH, Barrajón-Catalán E and García-Pérez JV, Air-borne ultrasonic application in the drying of grape skin: Kinetic and quality considerations. J Food Eng 168: 251-258 (2016).

72. do Nascimento EMGC, Mulet A, Ascheri JLR, de Carvalho CWP and Cárcel JA, Effects of high-intensity ultrasound on drying kinetics and antioxidant properties of passion fruit peel. J Food Eng 170: 108-118 (2016).

73. Szadzińska J, Kowalski SJ and Stasiak M, Microwave and ultrasound enhancement of convective drying of strawberries: Experimental and modeling efficiency. Int J Heat Mass Tran 103: 1065-1074 (2016).

74. Szadzińska J, Łechtańska J, Kowalski SJ and Stasiak M, The effect of high power airborne ultrasound and microwaves on convective drying effectiveness and quality of green pepper. Ultrason Sonochem 34: 531-539 (2017).

75. Fonteles TV, Leite AKF, Silva ARA, Carneiro APG, Miguel EdC, Cavada BS; Fernandes FAN and Rodrigues S, Ultrasound processing to enhance drying of cashew apple bagasse puree: Influence on antioxidant properties and in vitro bioaccessibility of bioactive compounds. Ultrason Sonochem 31: 237-249 (2016).

76. Boukouvalas CJ, Krokida MK, Maroulis ZB and Marinos-Kouris D, Density and porosity: literature data compilation for foodstuffs. Int J Food Prop 9: 715-746 (2006).

77. Ozuna C, Cárcel JA, Walde PM and Garcia-Perez JV, Low-temperature drying of salted cod (Gadus morhua) assisted by high power ultrasound: Kinetics and physical properties. Innov Food Sci Emerg 23: 146-155 (2014).

78. Chen Z-G, Guo X-Y and Wu T, A novel dehydration technique for carrot slices implementing ultrasound and vacuum drying methods. Ultrason Sonochem 30: 28-34 (2016).

79. Santacatalina JV, Soriano JR, Cárcel JA and Garcia-Perez JV, Influence of air velocity and temperature on ultrasonically assisted low temperature drying of eggplant. Food Bioprod Process 100: 282-291 (2016).

80. Musielak G, Mierzwa D and Kroehnke J, Food drying enhancement by ultrasound - A review. Trends Food Sci Tech 56: 126-141 (2016).

81. Francis FJ and Clydesdale FM, Food Colorimetry: Theory And Applications, ed.The Avi Publishing Company, Inc., pp. 90-91(1977).

82. Kowalski SJ and Szadzińska J, Convective-intermittent drying of cherries preceded by ultrasonic assisted osmotic dehydration. Chem Eng Process 82, 65-70 (2014).

83. Pérez-Jiménez J, Díaz-Rubio ME and Saura-Calixto F, Non-extractable polyphenols in plant foods: nature, isolation, and analysis, in Polyphenols in Plants, ed. Academic Press, San Diego, pp. 203-218 (2014).

84. Ainsworth EA and Gillespie KM, Estimation of total phenolic content and other oxidation substrates in plant tissues using Folin-Ciocalteu reagent. Nat Protoc 2: 875-877 (2007).

85. Gamboa-Santos J, Soria AC, Villamiel M and Montilla A, Quality parameters in convective dehydrated carrots blanched by ultrasound and conventional treatment. Food Chem 141: 616-624 (2013).

86. Kadam SU, Tiwari BK and O'Donnell CP, Effect of ultrasound pre-treatment on the drying kinetics of brown seaweed Ascophyllum nodosum. Ultrason Sonochem 23: 302-307 (2015).

87. Santacatalina JV, Cárcel JA, Simal S, Garcia-Perez JV and Mulet A, Atmospheric freeze drying assisted by power ultrasound. IOP Conf Ser-Mat Sci 42: 012021 (2012).

This article is protected by copyright. All rights reserved. 
Table 1. Application of power ultrasound as pretreatment before drying. Ultrasonic devices, pretreatment and drying conditions, and quality parameters under study.

\begin{tabular}{|c|c|c|c|c|c|c|}
\hline \multirow[b]{2}{*}{ Product } & \multicolumn{3}{|c|}{$\begin{array}{l}\text { Acoustically assisted } \\
\text { pretreatment }\end{array}$} & \multirow[b]{2}{*}{$\begin{array}{l}\text { Drying } \\
\text { conditio } \\
\text { ns }\end{array}$} & \multirow[b]{2}{*}{$\begin{array}{c}\text { Quality } \\
\text { parameters }\end{array}$} & \multirow[b]{2}{*}{$\begin{array}{c}\text { Referen } \\
\text { ce }\end{array}$} \\
\hline & $\begin{array}{c}\text { Ultraso } \\
\text { nic } \\
\text { Device }\end{array}$ & $\begin{array}{c}\text { Pretreatm } \\
\text { ent } \\
\text { Condition } \\
\text { s }\end{array}$ & $\begin{array}{l}\text { Mediu } \\
\text { m }\end{array}$ & & & \\
\hline $\begin{array}{c}\text { Apple } \\
\text { Malus } \\
\text { domestica } \\
\text { var Red } \\
\text { Fuji }\end{array}$ & Probe & $\begin{array}{c}25 \mathrm{kHz} \\
200 \mathrm{~W} \\
5-15 \mathrm{~min}\end{array}$ & $\begin{array}{l}\text { Distill } \\
\text { ed } \\
\text { water }\end{array}$ & $\begin{array}{c}70^{\circ} \mathrm{C} \\
75 \mathrm{~W} / \mathrm{g}^{*}\end{array}$ & $\begin{array}{c}\text { Color; Texture; } \\
\text { Rehydration; } \\
\text { Water } \\
\text { distribution }\end{array}$ & 41 \\
\hline $\begin{array}{c}\text { Apple } \\
\text { Malus } \\
\text { domestica } \\
\text { var. } \\
\text { Granny } \\
\text { Smith }\end{array}$ & Probe & $\begin{array}{c}0-12.9 \mathrm{~W} \\
\mathrm{~cm}^{-2} \\
25^{\circ} \mathrm{C} ; 5 \\
\min \end{array}$ & $\begin{array}{l}\text { Distill } \\
\text { ed } \\
\text { water } \\
1 \% \\
\text { citric } \\
\text { acid } \\
\text { Juice }\end{array}$ & $\begin{array}{l}50^{\circ} \mathrm{C} \\
1 \mathrm{~m} \mathrm{~s}^{-1}\end{array}$ & $\begin{array}{l}\text { Microstructure; } \\
\text { Enzymatic } \\
\text { activity; Water } \\
\text { distribution }\end{array}$ & 24 \\
\hline $\begin{array}{c}\text { Apple } \\
\text { Maus } \\
\text { domestica } \\
\text { Var. } \\
\text { Idared }\end{array}$ & Bath & $\begin{array}{c}35 \mathrm{kHz} \\
25^{\circ} \mathrm{C}, 10- \\
30 \mathrm{~min}\end{array}$ & $\begin{array}{l}\text { Distill } \\
\text { ed } \\
\text { water }\end{array}$ & $\begin{array}{c}70^{\circ} \mathrm{C} \\
1.5 \mathrm{~m} \mathrm{~s}^{-1}\end{array}$ & $\begin{array}{c}\text { Microstructure; } \\
\text { Rehydration, } \\
\text { Shrinkage, } \\
\text { Apparent } \\
\text { density, } \\
\text { Porosity, }\end{array}$ & 35 \\
\hline $\begin{array}{c}\text { Apple } \\
\text { Maus } \\
\text { domestica } \\
\text { Var. } \\
\text { Idared }\end{array}$ & Bath & $\begin{array}{c}21,35 \\
\mathrm{kHz} ; 3,4 \\
\mathrm{~W} \mathrm{~cm} \mathrm{~cm}^{-2} \\
30 \mathrm{~min}\end{array}$ & $\begin{array}{l}\text { Distill } \\
\text { ed } \\
\text { water }\end{array}$ & $\begin{array}{l}70^{\circ} \mathrm{C} \\
2 \mathrm{~m} \mathrm{~s}^{-1}\end{array}$ & $\begin{array}{c}\text { Color; } \\
\text { Rehydration }\end{array}$ & 34 \\
\hline $\begin{array}{l}\text { Blackberry } \\
\text { Rubus } \\
\text { glaucus } \\
\text { Benth } \\
\text { var. } \\
\text { Andean }\end{array}$ & Probe & $\begin{array}{c}24 \mathrm{kHz} ; 85 \\
\mathrm{~W} \mathrm{~cm}^{-3} \\
15^{\circ} \mathrm{C}, 10- \\
30 \mathrm{~min}\end{array}$ & $\begin{array}{l}\text { Distill } \\
\text { ed } \\
\text { water }\end{array}$ & $\begin{array}{c}40-60 \\
{ }^{\circ} \mathrm{C} \\
3 \mathrm{~m} \mathrm{~s}^{-1}\end{array}$ & $\begin{array}{c}\text { Antioxidant } \\
\text { activity, }\end{array}$ & 22 \\
\hline $\begin{array}{l}\text { Blueberry } \\
\text { Vaccinium } \\
\text { ashei } \\
\text { Reade }\end{array}$ & Probe & $\begin{array}{c}850 \mathrm{kHz}, \\
100 \mathrm{~W} \\
21^{\circ} \mathrm{C} ; 3 \mathrm{~h}\end{array}$ & $\begin{array}{c}55 \\
{ }^{\circ} \text { Brix }\end{array}$ & $70^{\circ} \mathrm{C}$ & $\begin{array}{l}\text { Color; Total } \\
\text { polyphenol and } \\
\text { anthocyanin } \\
\text { contents, } \\
\text { antioxidant } \\
\text { activity }\end{array}$ & 36 \\
\hline $\begin{array}{c}\text { Brown } \\
\text { seaweed }\end{array}$ & Probe & $\begin{array}{c}7-76 \mathrm{~W} \\
\mathrm{~cm}^{-2} \\
10 \mathrm{~min}\end{array}$ & $\begin{array}{l}\text { Distill } \\
\text { ed } \\
\text { water }\end{array}$ & $\begin{array}{c}50^{\circ} \mathrm{C} \\
0.3 \mathrm{~m} \mathrm{~s}^{-1}\end{array}$ & Color & 88 \\
\hline
\end{tabular}

This article is protected by copyright. All rights reserved. 


\begin{tabular}{|c|c|c|c|c|c|c|}
\hline $\begin{array}{c}\text { Ascophyllu } \\
m \\
\text { nodosum }\end{array}$ & & & & & & \\
\hline $\begin{array}{c}\text { Brussels } \\
\text { sprout } \\
\text { Brassica } \\
\text { oleracea } \\
\text { var. } \\
\text { gemmifera }\end{array}$ & $\begin{array}{c}\text { Bath/Pro } \\
\text { be }\end{array}$ & $\begin{array}{c}20-24 \\
\mathrm{kHz} ; \\
0.5-43 \mathrm{~W} \\
\mathrm{~cm}^{-2} / \\
18^{\circ} \mathrm{C} ; 3- \\
10 \mathrm{~min}\end{array}$ & $\begin{array}{c}\text { Distill } \\
\text { ed } \\
\text { water }\end{array}$ & $\begin{array}{c}60^{\circ} \mathrm{C} \\
0.3 \mathrm{~m} \mathrm{~s}^{-1}\end{array}$ & Rehydration & 25 \\
\hline $\begin{array}{c}\text { Carrot } \\
\text { Daucus } \\
\text { carota L. }\end{array}$ & Bath & $\begin{array}{c}38 \mathrm{kHz} \\
320 \mathrm{~W} \\
25 \mathrm{C} ; 120 \\
\min \end{array}$ & $\begin{array}{l}40,60 \\
{ }^{\circ} \text { Brix }\end{array}$ & $\begin{array}{c}70^{\circ} \mathrm{C} \\
1.1 \mathrm{~m} \mathrm{~s}^{-1}\end{array}$ & Color & 48 \\
\hline $\begin{array}{c}\text { Carrot } \\
\text { Daucus } \\
\text { carota L. } \\
\text { var. } \\
\text { Nantesa }\end{array}$ & Probe & $\begin{array}{c}20 \mathrm{kHz} \\
400 \mathrm{~W} \\
60-70{ }^{\circ} \mathrm{C} ; \\
10-15 \\
\min \end{array}$ & $\begin{array}{c}\text { Distill } \\
\text { ed } \\
\text { water }\end{array}$ & $\begin{array}{c}46^{\circ} \mathrm{C} ; \\
4.9 \mathrm{~m} \mathrm{~s}^{-1}\end{array}$ & $\begin{array}{c}\text { Microstructure; } \\
\text { Rehydration } \\
\text { Protein profile; } \\
\text { Total } \\
\text { polyphenol } \\
\text { content } \\
\text { Soluble } \\
\text { carbohydrates; } \\
\text { 2-FM-AA } \\
\text { content }\end{array}$ & 87 \\
\hline $\begin{array}{l}\text { Carrot } \\
\text { Daucus } \\
\text { carota L } \\
\text { var. } \\
\text { Flakee }\end{array}$ & Bath & $\begin{array}{c}25 \mathrm{kHz}, \\
700 \mathrm{~W} \\
23^{\circ} \mathrm{C} ; 30- \\
60 \mathrm{~min}\end{array}$ & $\begin{array}{c}\text { Distill } \\
\text { ed } \\
\text { water }\end{array}$ & $\begin{array}{c}40-60 \\
{ }^{\circ} \mathrm{C} ; \\
2 \mathrm{~m} \mathrm{~s}^{-1}\end{array}$ & Rehydration & 20 \\
\hline $\begin{array}{c}\text { Carrot } \\
\text { Daucus } \\
\text { carota L } \\
\text { var. Nerac }\end{array}$ & Probe & $\begin{array}{c}20 \mathrm{kHz} \\
0.4-1.0 \mathrm{~W} \\
\mathrm{~mL}^{-1} \\
25^{\circ} \mathrm{C} ; 3 \\
10 \mathrm{~min}\end{array}$ & $\begin{array}{c}\text { Distill } \\
\text { ed } \\
\text { water }\end{array}$ & $\begin{array}{c}60^{\circ} \mathrm{C} \\
0.3 \mathrm{~m} \mathrm{~s}^{-1}\end{array}$ & $\begin{array}{c}\text { Color, } \\
\text { Polyacetylene } \\
\text { and total } \\
\text { carotenoid } \\
\text { contents }\end{array}$ & 42 \\
\hline $\begin{array}{c}\text { Cashew } \\
\text { apple } \\
\text { baggase } \\
\text { Anacardiu } \\
m \\
\text { occidental } \\
\text { e L. }\end{array}$ & Probe & $\begin{array}{c}20 \mathrm{kHz} ; 75 \\
-373 \mathrm{~W} \\
\mathrm{~cm}^{-2} \\
20^{\circ} \mathrm{C} ; 2- \\
10 \mathrm{~min}\end{array}$ & $\begin{array}{c}\text { Distill } \\
\text { ed } \\
\text { water }\end{array}$ & $\begin{array}{l}60^{\circ} \mathrm{C} \\
1 \mathrm{~m} \mathrm{~s}^{-1}\end{array}$ & $\begin{array}{c}\text { Microstructure, } \\
\text { Color, } \\
\text { Antioxidant } \\
\text { activity, } \\
\text { Vitamin C } \\
\text { content, } \\
\text { Enzymatic } \\
\text { activity }\end{array}$ & 77 \\
\hline $\begin{array}{c}\text { Cauliflowe } \\
\text { r } \\
\text { Brassica } \\
\text { oleracea } \\
\text { var. } \\
\text { botrytis }\end{array}$ & $\begin{array}{c}\text { Bath/Pro } \\
\text { be }\end{array}$ & $\begin{array}{c}20-24 \\
\mathrm{kHz} ; \\
0.5-43 \mathrm{~W} \\
\mathrm{~cm}^{-2} / \\
18^{\circ} \mathrm{C} ; 3- \\
10 \mathrm{~min}\end{array}$ & $\begin{array}{c}\text { Distill } \\
\text { ed } \\
\text { water }\end{array}$ & $\begin{array}{c}60^{\circ} \mathrm{C} \\
0.3 \mathrm{~m} \mathrm{~s}^{-1}\end{array}$ & Rehydration & 25 \\
\hline $\begin{array}{l}\text { Cherries } \\
\text { P. cerasus } \\
\text { L. }\end{array}$ & Bath & $\begin{array}{c}25 \mathrm{kHz} \\
700 \mathrm{~W}\end{array}$ & $\begin{array}{c}60 \\
{ }^{\circ} \text { Brix }\end{array}$ & $60^{\circ} \mathrm{C}$ & Color & 84 \\
\hline
\end{tabular}

This article is protected by copyright. All rights reserved. 
$25^{\circ} \mathrm{C} ; 30$

min

\begin{tabular}{|c|c|c|c|c|c|c|}
\hline $\begin{array}{c}\text { Cherries } \\
\text { P. cerasus } \\
\text { L. }\end{array}$ & Bath & $\begin{array}{c}25 \mathrm{kHz} \\
0.4 \mathrm{~W} \mathrm{~cm}^{-2} \\
40{ }^{\circ} \mathrm{C} ; 0- \\
120 \mathrm{~min}\end{array}$ & $\begin{array}{c}60 \\
{ }^{\circ} \text { Brix }\end{array}$ & $\begin{array}{c}60^{\circ} \mathrm{C} \\
2.5 \mathrm{~m} \mathrm{~s}^{-1}\end{array}$ & $\begin{array}{c}\text { Microstructure, } \\
\text { Total } \\
\text { phenoli } \\
\text { c and } \\
\text { anthocy } \\
\text { anin } \\
\text { contents } \\
\end{array}$ & 37 \\
\hline $\begin{array}{c}\text { Guava } \\
\text { Psidium } \\
\text { guajava }\end{array}$ & Bath & $\begin{array}{c}25 \mathrm{kHz} ; 0 \\
-2.5 \mathrm{~kW} \\
30{ }^{\circ} \mathrm{C} ; 20- \\
60 \mathrm{~min}\end{array}$ & $\begin{array}{l}0-70 \\
{ }^{\circ} \text { Brix }\end{array}$ & $\begin{array}{c}70{ }^{\circ} \mathrm{C} \\
0.06 \mathrm{~m} \\
\mathrm{~s}^{-1}\end{array}$ & $\begin{array}{l}\text { Color; Texture; } \\
\text { Vitamin C } \\
\text { content }\end{array}$ & 19 \\
\hline $\begin{array}{l}\text { Guava } \\
\text { Psidium } \\
\text { guajava }\end{array}$ & Probe & $\begin{array}{c}20 \mathrm{kHz} \\
400 \mathrm{~W} \\
6-20 \mathrm{~min}\end{array}$ & $\begin{array}{l}0-70 \\
{ }^{\circ} \text { Brix }\end{array}$ & $\begin{array}{c}70{ }^{\circ} \mathrm{C} \\
0.06 \mathrm{~m} \\
\mathrm{~s}^{-1}\end{array}$ & $\begin{array}{l}\text { Color; Texture; } \\
\text { Vitamin C } \\
\text { content }\end{array}$ & 19 \\
\hline $\begin{array}{c}\text { Malay } \\
\text { apple } \\
\text { Syzygium } \\
\text { malaccens } \\
\text { e L. }\end{array}$ & Bath & $\begin{array}{c}25 \mathrm{kHz} ; 60 \\
\mathrm{~W} \\
25^{\circ} \mathrm{C} ; 10- \\
60 \mathrm{~min}\end{array}$ & $\begin{array}{c}25- \\
50 \\
{ }^{\circ} \text { Brix }\end{array}$ & $60^{\circ} \mathrm{C}$ & Microstructure & 38 \\
\hline Melon & Bath & $\begin{array}{c}25 \mathrm{kHz}, \\
4.9 \mathrm{~kW} / \mathrm{m}^{-2} \\
30^{\circ} \mathrm{C} ; 20- \\
30 \mathrm{~min}\end{array}$ & $\begin{array}{l}\text { Distill } \\
\text { ed } \\
\text { water }\end{array}$ & $60^{\circ} \mathrm{C}$ & Microstructure & 26 \\
\hline $\begin{array}{l}\text { Melon } \\
\text { Cucumis } \\
\text { melo L. } \\
\text { Var. } \\
\text { cantalupen } \\
\text { sis Naud }\end{array}$ & Bath & $\begin{array}{c}25 \mathrm{kHz} ; \\
4.9 \mathrm{~kW} \mathrm{~m}^{-2} \\
30{ }^{\circ} \mathrm{C} ; 10- \\
30 \mathrm{~min} \\
0.02-0.03 \\
\mathrm{MPa}\end{array}$ & $\begin{array}{l}\text { Distill } \\
\text { ed } \\
\text { water }\end{array}$ & $\begin{array}{c}60^{\circ} \mathrm{C} \\
2.0 \mathrm{~m} \mathrm{~s}^{-1}\end{array}$ & $\begin{array}{c}\text { Color; Texture, } \\
\text { Total } \\
\text { carotenoid } \\
\text { content; } \\
\text { Sensory } \\
\text { analysis }\end{array}$ & 45 \\
\hline $\begin{array}{l}\text { Mulberry } \\
\text { leaves } \\
\text { Morus } \\
\text { alba L. }\end{array}$ & Probe & $\begin{array}{c}25.2-117.6 \\
\mathrm{~W} \mathrm{~L} \mathrm{~L}^{-1} \\
20{ }^{\circ} \mathrm{C} ; 5- \\
15 \mathrm{~min}\end{array}$ & $\begin{array}{l}\text { Distill } \\
\text { ed } \\
\text { water }\end{array}$ & $\begin{array}{c}60^{\circ} \mathrm{C} \\
2.5 \mathrm{~m} \mathrm{~s}^{-1}\end{array}$ & $\begin{array}{c}\text { Color, Phenolic } \\
\text { and flavonoid } \\
\text { contents, } \\
\text { Antioxidant } \\
\text { activity, } \\
\text { Chlorophylls, } \\
1 \text { - } \\
\text { deoxynojirimyc } \\
\text { in and y- } \\
\text { aminobutyric } \\
\text { acid contents }\end{array}$ & 43 \\
\hline $\begin{array}{l}\text { Mushroom } \\
\text { Agaricus } \\
\text { biosporus }\end{array}$ & Bath & $\begin{array}{c}35 \mathrm{kHz} ; \\
480 \mathrm{~W} \\
30^{\circ} \mathrm{C} ; 10- \\
30 \mathrm{~min}\end{array}$ & $\begin{array}{l}\text { Distill } \\
\text { ed } \\
\text { water }\end{array}$ & $\begin{array}{c}50^{\circ} \mathrm{C} \\
1.5 \mathrm{~m} \mathrm{~s}^{-1}\end{array}$ & $\begin{array}{c}\text { Rehydration, } \\
\text { Total } \\
\text { polyphenol } \\
\text { content }\end{array}$ & 39 \\
\hline $\begin{array}{l}\text { Mushroom } \\
\text { Agaricus } \\
\text { biosporus }\end{array}$ & $\begin{array}{c}\text { Bath/Pro } \\
\text { be }\end{array}$ & $\begin{array}{c}20-24 \\
\mathrm{kHz}\end{array}$ & $\begin{array}{l}\text { Distill } \\
\text { ed } \\
\text { water }\end{array}$ & $\begin{array}{c}60{ }^{\circ} \mathrm{C} \\
0.3 \mathrm{~m} \mathrm{~s}^{-1}\end{array}$ & Rehydration & 25 \\
\hline
\end{tabular}

This article is protected by copyright. All rights reserved. 


\begin{tabular}{|c|c|c|c|c|c|c|}
\hline & & $\begin{array}{c}0.5-43 \\
\mathrm{~W} \mathrm{~cm} \mathrm{~cm}^{-2} \\
18^{\circ} \mathrm{C} ; 3- \\
10 \mathrm{~min}\end{array}$ & & & & \\
\hline $\begin{array}{c}\text { Parsley } \\
\text { leaves } \\
\text { Petroselin } \\
\text { um } \\
\text { crispum }\end{array}$ & Bath & $\begin{array}{c}21 \mathrm{kHz} \\
300 \mathrm{~W} \\
22^{\circ} \mathrm{C} ; 20 \\
\min \end{array}$ & $\begin{array}{l}\text { Distill } \\
\text { ed } \\
\text { water }\end{array}$ & $\begin{array}{c}20-40 \\
{ }^{\circ} \mathrm{C} \\
0.7 \mathrm{~m} \mathrm{~s}^{-1} \\
100- \\
400 \mathrm{~W}^{*}\end{array}$ & $\begin{array}{c}\text { Color; } \\
\text { Chlorophyll } \\
\text { content; Lutein } \\
\text { content }\end{array}$ & 44 \\
\hline $\begin{array}{c}\text { Papaya } \\
\text { Carica } \\
\text { papaya } \\
\text { var. } \\
\text { Formosa }\end{array}$ & Bath & $\begin{array}{c}25 \mathrm{kHz} ; \\
4.9 \mathrm{~kW} \mathrm{~m}{ }^{-2} \\
30{ }^{\circ} \mathrm{C} ; 10- \\
30 \mathrm{~min}\end{array}$ & $\begin{array}{l}0-56 \\
\text { Brix; }\end{array}$ & $\begin{array}{c}70^{\circ} \mathrm{C} \\
2.0 \mathrm{~m} \mathrm{~s}^{-1}\end{array}$ & $\begin{array}{c}\text { Total } \\
\text { carotenoid } \\
\text { content }\end{array}$ & 40 \\
\hline $\begin{array}{c}\text { Pineapple } \\
\text { Ananas } \\
\text { comosus } \\
\text { var. } \\
\text { Perola }\end{array}$ & Bath & $\begin{array}{c}25 \mathrm{kHz} ; \\
5.1 \mathrm{~W} \mathrm{~L}^{-1} \\
30{ }^{\circ} \mathrm{C} ; 10- \\
30 \mathrm{~min}\end{array}$ & $\begin{array}{l}\text { Distill } \\
\text { ed } \\
\text { water } \\
\text { Juice }\end{array}$ & $\begin{array}{c}50^{\circ} \mathrm{C} \\
0.5 \mathrm{~m} \mathrm{~s}^{-1}\end{array}$ & $\begin{array}{c}\text { Vitamins } \mathrm{C}, \mathrm{B}_{1} \text {, } \\
\mathrm{B}_{2}, \mathrm{~B}_{3}, \mathrm{~B}_{5}, \\
\text { organic acids; } \\
\text { Total } \\
\text { polyphenol and } \\
\text { flavonoid } \\
\text { contents; } \\
\text { Antioxidant } \\
\text { activity }\end{array}$ & 33 \\
\hline $\begin{array}{c}\text { Strawberry } \\
\text { Fragaria } \\
\text { ananassa } \\
\text { var. } \\
\text { Camarasa }\end{array}$ & Bath & $\begin{array}{c}0-40 \mathrm{kHz} \\
30{ }^{\circ} \mathrm{C} ; 10- \\
45 \mathrm{~min}\end{array}$ & $\begin{array}{c}25,50 \\
{ }^{\circ} \text { Brix }\end{array}$ & $\begin{array}{c}60{ }^{\circ} \mathrm{C} \\
0.5 \mathrm{~m} \mathrm{~s}^{-} \\
1\end{array}$ & Microstructure & 47 \\
\hline
\end{tabular}

Table 2. Application of power ultrasound during convective drying. Conditions and quality parameters under study.

\begin{tabular}{|c|c|c|c|c|c|}
\hline \multirow[b]{2}{*}{ Product } & \multicolumn{3}{|c|}{ Acoustically assisted drying } & \multirow[b]{2}{*}{$\begin{array}{c}\text { Quality } \\
\text { parameters }\end{array}$} & \multirow[b]{2}{*}{ Reference } \\
\hline & $\begin{array}{l}\text { Ultrasonic } \\
\text { Device }\end{array}$ & $\begin{array}{l}\text { Ultrasonic } \\
\text { parameter }\end{array}$ & $\begin{array}{l}\text { Drying } \\
\text { conditions }\end{array}$ & & \\
\hline $\begin{array}{c}\text { Apple } \\
\text { Malus } \\
\text { domestica } \\
\text { var. Granny } \\
\text { Smith }\end{array}$ & $\begin{array}{c}\text { Flexural } \\
\text { vibrating } \\
\text { plate }\end{array}$ & $\begin{array}{c}20 \mathrm{kHz} \\
20-90 \mathrm{~W}\end{array}$ & $\begin{array}{c}40-60^{\circ} \mathrm{C} \\
1 \mathrm{~m} \mathrm{~s}^{-1}\end{array}$ & $\begin{array}{l}\text { Microstructure, } \\
\text { Texture }\end{array}$ & 53 \\
\hline $\begin{array}{c}\text { Apple } \\
\text { Malus } \\
\text { domestica } \\
\text { var. Granny } \\
\text { Smith }\end{array}$ & $\begin{array}{l}\text { Aluminum } \\
\text { vibrating } \\
\text { cylinder }\end{array}$ & $\begin{array}{c}21.8 \mathrm{kHz} \\
0-31 \mathrm{~kW} \\
\mathrm{~m}^{-3}\end{array}$ & $\begin{array}{l}40^{\circ} \mathrm{C} \\
1 \mathrm{~m} \mathrm{~s}^{-1}\end{array}$ & $\begin{array}{l}\text { Microstructure, } \\
\text { Porosity, Texture }\end{array}$ & 4 \\
\hline $\begin{array}{c}\text { Apple } \\
\text { Malus } \\
\text { domestica }\end{array}$ & $\begin{array}{l}\text { Aluminum } \\
\text { vibrating } \\
\text { cylinder }\end{array}$ & $25-75 \mathrm{~W}$ & $\begin{array}{c}-10-10 \\
{ }^{\circ} \mathrm{C} \\
2 \mathrm{~m}^{-1}\end{array}$ & $\begin{array}{c}\text { Rehydration, } \\
\text { Hardness, } \\
\text { Texture, }\end{array}$ & 23 \\
\hline
\end{tabular}

This article is protected by copyright. All rights reserved. 


\begin{tabular}{|c|c|c|c|c|c|}
\hline $\begin{array}{l}\text { var. Granny } \\
\text { Smith }\end{array}$ & & & & $\begin{array}{l}\text { Antioxidant } \\
\text { activity }\end{array}$ & \\
\hline $\begin{array}{c}\text { Apple } \\
\text { Malus } \\
\text { domestica } \\
\text { var. Granny } \\
\text { Smith }\end{array}$ & $\begin{array}{l}\text { Aluminum } \\
\text { vibrating } \\
\text { cylinder }\end{array}$ & $\begin{array}{c}21.8 \mathrm{kHz} \\
18.5-30.8 \\
\mathrm{~kW} \mathrm{~m} \mathrm{~m}^{-3}\end{array}$ & $\begin{array}{c}30-70^{\circ} \mathrm{C} \\
1 \mathrm{~m} \mathrm{~s}^{-1}\end{array}$ & $\begin{array}{l}\text { Microstructure; } \\
\text { Total polyphenol } \\
\text { and flavonoid } \\
\text { contents, } \\
\text { Antioxidant } \\
\text { activity }\end{array}$ & 66 \\
\hline $\begin{array}{c}\text { Apple } \\
\text { Malus } \\
\text { domestica } \\
\text { var. Granny } \\
\text { Smith }\end{array}$ & $\begin{array}{l}\text { Aluminum } \\
\text { vibrating } \\
\text { cylinder }\end{array}$ & $\begin{array}{c}20.5 \mathrm{~kW} \\
\mathrm{~m}^{-3}\end{array}$ & $\begin{array}{l}-10-10 \\
{ }^{\circ} \mathrm{C} \\
2 \mathrm{~m} \mathrm{~s}^{-1}\end{array}$ & $\begin{array}{l}\text { Polyphenol and } \\
\text { flavonoid } \\
\text { contents, } \\
\text { antioxidant } \\
\text { activity }\end{array}$ & 67 \\
\hline $\begin{array}{c}\text { Apple } \\
\text { Malus } \\
\text { domestica L. }\end{array}$ & $\begin{array}{l}\text { Aluminum } \\
\text { vibrating } \\
\text { cylinder }\end{array}$ & $\begin{array}{c}21.7 \mathrm{kHz} \\
75 \mathrm{~W}\end{array}$ & $\begin{array}{c}45,60 \mathrm{C} \\
1-5 \mathrm{~m} \mathrm{~s}^{-1}\end{array}$ & $\begin{array}{l}\text { Vitamins } \mathrm{A}, \mathrm{B}_{1} \text {, } \\
\mathrm{B}_{2}, \mathrm{~B}_{3}, \mathrm{~B}_{5}, \mathrm{~B}_{6} \\
\text { and } \mathrm{E}\end{array}$ & 1 \\
\hline $\begin{array}{c}\text { Carrot } \\
\text { Daucus } \\
\text { carota L. } \\
\text { var. Nantesa }\end{array}$ & $\begin{array}{l}\text { Aluminum } \\
\text { vibrating } \\
\text { cylinder }\end{array}$ & $\begin{array}{c}20 \mathrm{kHz}^{-} \\
100 \mathrm{~W} \mathrm{~cm}^{-} \\
2\end{array}$ & $\begin{array}{r}20-60^{\circ} \mathrm{C} \\
1,2 \mathrm{~m} \mathrm{~s}^{-1}\end{array}$ & $\begin{array}{l}\text { Vitamin } \mathrm{C} \text { and } \beta \text { - } \\
\text { carotene contents }\end{array}$ & 59 \\
\hline $\begin{array}{c}\text { Carrot } \\
\text { Daucus } \\
\text { carota L. } \\
\text { var. Nantesa }\end{array}$ & $\begin{array}{l}\text { Aluminum } \\
\text { vibrating } \\
\text { cylinder }\end{array}$ & $\begin{array}{c}0-2.5 \mathrm{~kW} \\
\mathrm{~m}^{-3}\end{array}$ & $\begin{array}{l}-10{ }^{\circ} \mathrm{C} \\
2 \mathrm{~m} \mathrm{~s}^{-1}\end{array}$ & $\begin{array}{l}\text { Rehydration, } \\
\text { Texture }\end{array}$ & 89 \\
\hline $\begin{array}{l}\text { Cassava } \\
\text { Manihot } \\
\text { esculenta }\end{array}$ & $\begin{array}{l}\text { Aluminum } \\
\text { vibrating } \\
\text { cylinder }\end{array}$ & $\begin{array}{c}21.8 \mathrm{kHz} \\
0-31 \mathrm{~kW} \\
\mathrm{~m}^{-3}\end{array}$ & $\begin{array}{l}40^{\circ} \mathrm{C} \\
1 \mathrm{~m} \mathrm{~s}^{-1}\end{array}$ & $\begin{array}{l}\text { Microstructure, } \\
\text { Porosity, Texture }\end{array}$ & 4 \\
\hline $\begin{array}{l}\text { Red pepper } \\
\text { Capsicum } \\
\text { annuиm } L\end{array}$ & $\begin{array}{c}\text { Ring } \\
\text { sonotrode }\end{array}$ & $\begin{array}{c}76-110 \\
W\end{array}$ & $\begin{array}{l}-30{ }^{\circ} \mathrm{C} \\
46 \mathrm{~Pa}\end{array}$ & $\begin{array}{l}\text { Bulk density, } \\
\text { Rehydration, } \\
\text { Color, Ascorbic } \\
\text { acid content }\end{array}$ & 63 \\
\hline $\begin{array}{c}\text { Cherry } \\
\text { tomato } \\
\text { Solanum } \\
\text { lycopersicum } \\
\text { var. } \\
\text { Cerasiforme }\end{array}$ & $\begin{array}{l}\text { Aluminum } \\
\text { vibrating } \\
\text { cylinder }\end{array}$ & $\begin{array}{c}21.7 \mathrm{kHz} \\
75 \mathrm{~W}\end{array}$ & $\begin{array}{l}45,60{ }^{\circ} \mathrm{C} \\
1-3 \mathrm{~m} \mathrm{~s}^{-1}\end{array}$ & $\begin{array}{l}\text { Vitamins } \mathrm{B}_{1}, \mathrm{~B}_{2}, \\
\mathrm{~B}_{3}, \mathrm{~B}_{5}, \mathrm{~B}_{6} \text { and } \mathrm{E}, \\
\text { Lycopene and } \beta- \\
\text { carotene } \\
\text { contents, }\end{array}$ & 69 \\
\hline $\begin{array}{l}\text { Eggplant } \\
\text { Solanum } \\
\text { melongena } \\
\text { L. }\end{array}$ & $\begin{array}{l}\text { Aluminum } \\
\text { vibrating } \\
\text { cylinder }\end{array}$ & $\begin{array}{c}21.7 \mathrm{kHz} \\
18.5-37.0 \\
\mathrm{~W} \mathrm{~L}^{-1}\end{array}$ & $\begin{array}{l}40^{\circ} \mathrm{C} \\
1 \mathrm{~m} \mathrm{~s}^{-1}\end{array}$ & Microstructure & 72 \\
\hline $\begin{array}{l}\text { Eggplant } \\
\text { Solanum } \\
\text { melongena } \\
\text { L. }\end{array}$ & $\begin{array}{l}\text { Aluminum } \\
\text { vibrating } \\
\text { cylinder }\end{array}$ & $\begin{array}{c}21.9 \mathrm{kHz} \\
90 \mathrm{~W}\end{array}$ & $\begin{array}{c}-10-10 \\
{ }^{\circ} \mathrm{C} \\
1 \mathrm{~m} \mathrm{~s}^{-1}\end{array}$ & $\begin{array}{l}\text { Hardness, } \\
\text { rehydration, oil } \\
\text { intake }\end{array}$ & 81 \\
\hline $\begin{array}{c}\text { Grape skin } \\
\text { Vitis vinifera } \\
\text { L. } \\
\text { var Bobal }\end{array}$ & $\begin{array}{l}\text { Aluminum } \\
\text { vibrating } \\
\text { cylinder }\end{array}$ & $45 \mathrm{~W}$ & $\begin{array}{c}40-70^{\circ} \mathrm{C} \\
1 \mathrm{~m} \mathrm{~s}^{-1}\end{array}$ & $\begin{array}{l}\text { Antioxidant } \\
\text { activity, } \\
\text { polyphenolic } \\
\text { compounds }\end{array}$ & 73 \\
\hline
\end{tabular}

This article is protected by copyright. All rights reserved. 


\begin{tabular}{|c|c|c|c|c|c|}
\hline $\begin{array}{c}\text { Green } \\
\text { pepper } \\
\text { Capsicum } \\
\text { annuum L }\end{array}$ & $\begin{array}{c}\text { Ring } \\
\text { sonotrode }\end{array}$ & $\begin{array}{c}100-200 \\
\mathrm{~W} \\
46 \mathrm{~Pa}\end{array}$ & $\begin{array}{c}54^{\circ} \mathrm{C} \\
2.5 \mathrm{~m} \mathrm{~s}^{-1}\end{array}$ & $\begin{array}{c}\text { Color, vitamin } \mathrm{C} \\
\text { content }\end{array}$ & 76 \\
\hline $\begin{array}{l}\text { Orange peel } \\
\text { Citrus } \\
\text { sinensis } \\
\text { var. } \\
\text { Navelina }\end{array}$ & $\begin{array}{c}\text { Aluminum } \\
\text { vibrating } \\
\text { cylinder }\end{array}$ & $\begin{array}{l}21.8 \mathrm{kHz} \\
45,90 \mathrm{~W}\end{array}$ & $\begin{array}{l}40^{\circ} \mathrm{C} \\
1 \mathrm{~m} \mathrm{~s}^{-1}\end{array}$ & Microstructure & 70 \\
\hline $\begin{array}{l}\text { Passion fruit } \\
\text { peel }\end{array}$ & $\begin{array}{c}\text { Aluminum } \\
\text { vibrating } \\
\text { cylinder }\end{array}$ & $\begin{array}{c}21.7 \mathrm{kHz} \\
30.8 \mathrm{~kW} \\
\mathrm{~m}^{-3}\end{array}$ & $\begin{array}{c}40-70^{\circ} \mathrm{C} \\
1 \mathrm{~m} \mathrm{~s}^{-1}\end{array}$ & $\begin{array}{l}\text { Microstructure, } \\
\text { Antioxidant } \\
\text { capacity, total } \\
\text { polyphenol } \\
\text { content }\end{array}$ & 74 \\
\hline Potato & $\begin{array}{c}\text { Ring } \\
\text { sonotrode }\end{array}$ & $24 \mathrm{kHz}$ & $70^{\circ} \mathrm{C}$ & Microstructure & 61 \\
\hline $\begin{array}{c}\text { Raspberry } \\
\text { Rubus } \\
\text { idaeus L. }\end{array}$ & $\begin{array}{l}\text { Airborne } \\
\text { system }\end{array}$ & $\begin{array}{c}100-200 \\
W\end{array}$ & $\begin{array}{c}55^{\circ} \mathrm{C} \\
0.4 \mathrm{~m} \mathrm{~s}^{-1}\end{array}$ & Color & 60 \\
\hline $\begin{array}{c}\text { Strawberry } \\
\text { Fragaria } \\
\text { ananassa }\end{array}$ & $\begin{array}{c}\text { Ring } \\
\text { sonotrode }\end{array}$ & $\begin{array}{c}100-200 \\
W\end{array}$ & $\begin{array}{c}52{ }^{\circ} \mathrm{C} \\
2 \mathrm{~m} \mathrm{~s}^{-1}\end{array}$ & $\begin{array}{l}\text { Color, Water } \\
\text { activity }\end{array}$ & 75 \\
\hline $\begin{array}{c}\text { Strawberry } \\
\text { Fragaria } x \\
\text { ananassa } \\
\text { var. Duch. }\end{array}$ & $\begin{array}{l}\text { Aluminum } \\
\text { vibrating } \\
\text { cylinder }\end{array}$ & $\begin{array}{l}21.8 \mathrm{kHz} \\
30-60 \mathrm{~W}\end{array}$ & $\begin{array}{c}40-60{ }^{\circ} \mathrm{C} \\
2 \mathrm{~m} \mathrm{~s}^{-1}\end{array}$ & $\begin{array}{c}\text { Vitamin C } \\
\text { content, 2- } \\
\text { furoylmethyl } \\
\text { amino acids, } \\
\text { Microbiological } \\
\text { quality, }\end{array}$ & 51 \\
\hline
\end{tabular}

This article is protected by copyright. All rights reserved. 